Portland State University

PDXScholar

$3-6-2018$

\title{
Spatial Fields of Knowledge: How Public Library Architecture Performs Under Public and Context
}

Sofia Chavez Cruz

Portland State University

Follow this and additional works at: https://pdxscholar.library.pdx.edu/honorstheses

Let us know how access to this document benefits you.

Recommended Citation

Chavez Cruz, Sofia, "Spatial Fields of Knowledge: How Public Library Architecture Performs Under Public and Context" (2018). University Honors Theses. Paper 519.

https://doi.org/10.15760/honors.524

This Thesis is brought to you for free and open access. It has been accepted for inclusion in University Honors Theses by an authorized administrator of PDXScholar. Please contact us if we can make this document more accessible: pdxscholar@pdx.edu. 
Spatial Fields of Knowledge:

How Public Library Architecture Performs Under Public and Context

\section{by}

Sofia Chavez Cruz

An undergraduate honors thesis submitted in partial fulfillment of the

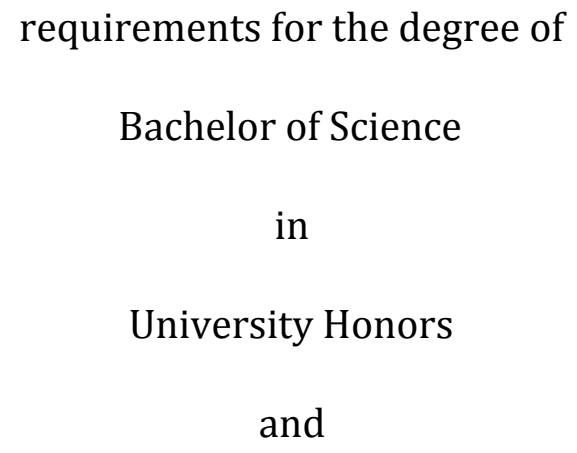

Thesis Adviser

Jeff Schnabel

Portland State University

2018 


\section{Spatial Fields of Knowledge:}

How Public Library Architecture Performs Under Public and Context 


\section{Contents}

00 Introduction

01 History of the Book, Circulating Library, and Beyond 5-9 02 Library as Context-Public 10-33

03 Bibliography 


\section{Introduction}

In defining the role of public library design in the 21 st century, it is critical to first consider the socio-cultural and economic forces that determine the omnidirectional expansions and contractions of its spaces. This type of public center has had the historically unique challenge of providing its visitors and/or users both spaces and resources that respond to the dynamics of social and technological situations. As newly constructed and renovated public libraries are designed to support a diverse interactive base, physical and digital information interfaces provide opportunities to explore their influence on increasingly responsive and transparent spaces. The internal, and to an extent, the external spaces of a library can be designed to respond to user needs while stimulating a combination of visual, intellectual, and social experiences. This paper presents a taxonomy on the present and possible futures of public library design through three lenses focusing on the library as a type of social environment, the visual and physical relationships between levels of public space, and the access to spatial fields of flexible interactivity. The following research takes into consideration the current developments and manipulations of the library as a composition of social production; while also exploring the history of books, book ownership, and readership as a transformation in individual and collective practice. The objective of this paper is to understand how the current spatial manipulations of library spaces, reacting to socio-cultural and public inputs may lead to a transformative urban typology of public library architecture. 


\section{History of the Book, Circulating Library, and Beyond}

To define the library as a physical and socio-cultural space is to explicate an expansive narrative of the book and its societal role in shaping the production and engagement of its content. The history of the book and readership is as much a testament to the power of religious and governmental entities in developing literary products as it is a practice in understanding the cultural functions by which the book collection evolved into a type of social information space. This section works to delineate a select history of the book as an object and spatial marker, as well as to investigate the transition of the book collection onto the public front.

The library as space presents a global history shaped by the creation, acquirement, and distribution of texts throughout ruling and monastic organizations. In the late 8th and 9th century, an awakening of cultural and educational influences within religious practices consequently shaped the production and readership of devotional literature ${ }^{1}$. However, in this period as in the decades before the mass output of texts, book ownership was by and large a privilege reserved for those within clergy, the ruling body, and nobility ${ }^{2}$. The book, with its intrinsic spatial parameters, can also be considered a guiding factor within the socio-cultural transformations of how literature was read and collected. In the case of religious materials during the 11th century, the delicate and painstakingly produced psalter was a liturgical collection of the Psalm scripture extensively utilized by clergy as well as the public ${ }^{3}$. The psalter, a significant part of daily religious devotion, was implemented in group recitations rather than forming part of independent reading. Examples of Byzantine psalters acquired by the British Library demonstrate the compactness of the physical object from 4" by 3" to 9" by 8"4. The scale of the book, typically no larger than the dimension of the palm of a hand reveal the mobility of literature where rather than it being stored, could be taken on journey and referenced in daily readings.

\footnotetext{
${ }^{1}$ Contreni, John. "The Carolingian Renaissance: Education and Literary Culture." Chapter. In The New Cambridge Medieval History, edited by Rosamond McKitterick, 2:709-57. The New Cambridge Medieval History. Cambridge: Cambridge University Press, 1995. doi:10.1017/CHOL9780521362924.030.

${ }^{2}$ Kalliroe Linardou, "Illuminated Byzantine Psalters”, The British Library: Greek Manuscripts. https://www.bl.uk/greek-manuscripts/articles/illuminated-byzantine-psalters\#

${ }^{3}$ Ibid.

${ }^{4}$ Ibid.
} 
Expanded readership in the Middle Ages continued the production of small scale book objects while influencing a broad fascination with illuminated literature. The book of hours, a highly decorated and illustrated religious text, represented a shift towards an individual connection with devotional reading as it did to introduce the book as a cultural signifier. The activity of reading a book of hours was organized into the main daily set of scriptures where the individual reading of sections were divided into hours of the day. ${ }^{5}$ Between the 15 th and and early 16th century, the text evolved from an original and personalized object to a widespread product accessible to those of a lower social status. By the early 1500s, following the development of printing, the book of hours was one of the most distributed books among a diverse group of social classes, serving to foment increased literacy and book ownership ${ }^{6}$. According to catalogued information by the British Library, examples of book of hours indicate the production of miniature literature objects ranging from 5" by 7" for a book produced in 15th century England, 5" by 3" for a French book of hours, and 3" by 2" for a book originating in the Netherlands at mid-end of the 15 th century. ${ }^{7}$ What unfolded as a result of a wider readership of the book of hours was a social inclination toward the collective practice of private reading ${ }^{8}$. The book, considered to be a "portable" type of literature due to its dimensions could be kept and transported on hand or fashioned onto a girdle belt ${ }^{9}$.

Transformations in intellectual, cultural, and religious processes during the Renaissance did not leave behind the innovations in printed text. Rather, the implementation of a mechanized output of distinguished 15th century literature, principally religious manuscripts, may have provided a foundation above which alternative socio-cultural discourses could be

\footnotetext{
${ }^{5}$ Bourkie, Andrew F. G., Alain Boureau, Marie-Elisabeth Ducreux, Christian Jouhaud, Paul Saenger, Catherine Velay-Vallantin, and Lydia G. Cochrane. The Culture of Print: Power and the Uses of Print in Early Modern Europe. Edited by Chartier Roger. Princeton University Press, 1989. http://www.jstor.org/stable/j.ctt7zvws2.

${ }^{6}$ Duffy, Eamon. Marking the Hours: English People and Their Prayers 1240-1570. Yale University Press, 2006; Stein, Wendy A. "The Book of Hours: A Medieval Bestseller." In Heilbrunn Timeline of Art History. New York: The Metropolitan Museum of Art, 2000-. http://www.metmuseum.org/toah/hd/hour/hd_hour.htm (June 2017); and Reinburg, Virginia. French Books of Hours: Making an Archive of Prayer, c. 1400-1600. Cambridge University Press, 2012. ${ }^{7}$ Book of Hours, Use of Sarum ("Anne Boleyn"s Book of Hours"),BL, Kings MS 9 : c 1500; Book of Hours, Use of Sarum, imperfect,BL.; Book of Hours, Book of Hours, Use of Rome ('The Dunois Hours'),BL.

${ }^{8}$ Saenger, Paul. Space Between Words: The Origins of Silent Reading. Stanford University Press, 1997.

9 "Illuminated Manuscripts Glossaries-Girdle book," British Library, http://www.bl.uk/catalogues/illuminatedmanuscripts/glossg.asp
} 
established. Around the same period that Johannes Gutenberg refined and eventually introduced his innovative printing process, the Vatican, under Pope Nicholas V was one of the first religious institutions in the mid 1400s to produce an extensive aggregation of secular and theological literature ${ }^{10}$. This move towards collected works spanning across multiple disciplines outside of religion, was in part a product of an increasingly humanistic approach in European thought. The study of Renaissance Humanism, which centered on the practice of "classical study", became one of the principle elements by which scholars translated a rhetoric of a "moral" and "rational" society" ${ }^{11}$ As the printing press enabled the formation of inquiry among an increasing readership, academic and scholarly practice influenced the expanding access to various literature and their reading. With the availability of multiple sources of texts from natural sciences to the classics of Cicero and Virgil, the readers of the late 1400s were now entrenched in the act of research, cross-reference, and collective discourse ${ }^{12}$. The possession of "a" book, as an item to be carried or worn, evolved into the social and economic activities of publishing, selling, owning, borrowing, and storing of multiple printed works. Aside from the main production of classical roman, greek, and religious texts, the enterprise of printing allowed the public dissemination of seminal literary works such as Dante's Divine Comedy, Pizan's The Book of the City of Ladies, Chaucer's Canterbury Tales, and two centuries later, Shakespeare's First Folio .

The printing and assembly of the book beyond the 15th century highly resembled the previous iterations of hand produced codices of monastic literature. Nonetheless, what the printed book displayed above all, was a refinement and application of an immediate output of composition, decoration and script manipulation, and binding techniques ${ }^{13}$. The common options of printed objects ranged from the royal folio, considered to be the largest book format typically sized at 20 " by 12 " to a smaller print, the medium octavo, sized around 9" by 5 "14. The

\footnotetext{
10 “The Promise of the Vatican Library," University of Nortre Dame and Vatican Library. https://vaticanlibrary.nd.edu/assets/197970/vatican_library_conference_program.pdf

${ }^{11}$ Gray, Hanna H. "Renaissance Humanism: The Pursuit of Eloquence." Journal of the History of Ideas 24, no. 4 (1963): 497-514. doi:10.2307/2707980.

${ }^{12}$ Mack, Peter. "Rhetoric, Ethics and Reading in the Renaissance." Renaissance Studies 19, no. 1 (2005): 1-21. http://www.jstor.org/stable/24416880.

${ }^{13}$ Chappell, Warren, and Robert Bringhurst. A Short History of the Printed Word. Hartley \& Marks Publishers, 1999.

14 “'The Shape of Paper,'Institut d'Histoire du Livre (Institute of the History of Books). http://ihl.enssib.fr/paper-and-watermarks-as-bibliographical-evidence/the-shape-of-paper
} 
dimension of most printed books included margin widths that could accommodate user and published annotation, in turn emphasizing reading as an academic and reflexive activity. The mass output of hardcover books and the subsequent version of the pamphlet introduced an "economical" means of partaking in reading. Literature in the form of paper-covered pamphlets were light and inexpensive to print which led to the possibility of their distribution across a broader social and urban landscape ${ }^{15}$.

Eventually, the book that could only be purchased or held by certain social groups was now a transformation of plurality; a collection of not only original bound manuscripts but modern literature printed and contained as valued possessions in the private libraries of prominent figures such as Henry VII, Cardinal Mazarin, the First Duke of Lauderdale, and Lovisa Ulrika of Prussia. In the 17th century, the "public library" in Western Europe was confined to certain geographical locations where it had been possible through an iterative and exhaustive collection process, to produce a library for those involved in academic and scholarly research. In the case of the Ambrosiana library in Milan, the Angelica library in Rome, and the Mazarine Library in Paris, their establishment was a result of extensive collections by members of clergy, that were brought to the public as a means of providing a diverse catalogue of classical to contemporary literature material. In Paris, the Mazarine collection under Cardinal Mazarin and librarian Gabriel Naude, became one of the first libraries in France to conduct as a public institution which would be "open to all the world without excluding a living human soul"16.

A century later, England's Georgian Era would provide the unique and social pleasures of a fee-based circulating library. This principle of literature distribution in exchange for a typical yearly membership would appear once again in the U.S cities of Boston and New York towards the end of $1700 \mathrm{~s}^{17}$. In London, the first examples of circulating libraries appear in the distributed fliers for the numerous volumes collected by bookshop keepers including the earliest recorded as that of Samuel Fancourt in 1748 and William Bathoe's in 1757. Both libraries provided more

\footnotetext{
${ }^{15}$ Walsby, Malcolm, and Graeme Kemp, eds. The book triumphant: print in transition in the sixteenth and seventeenth centuries. Vol. 9. Brill, 2011.

${ }^{16}$ Naudé, Gabriel, Victoria Richmond, John Cotton Dana, and Ruth Shepard Granniss. News from France, Or, A Description of the Library of Cardinal Mazarin Preceded by the Surrender of the Library (now Newly Translated): Two Tracts Written by Gabriel Naudé. AC McClurg, 1907.

17 Bolton, Charles Knowles. American Library History. No. 1. American library association publishing board, 1911.
} 
than 1,000 volumes to its members in the particular genres of "Romances [and] entertainment", plays, and cookery, most of which were uncommon in coexisting public libraries west of London or in the neighboring countries of France, Germany, and Italy ${ }^{18}$. The mechanisms of educational and scholarly discourse in the United States transitioned into the public sphere through the successive implementation of free lending public libraries. Before then, the materialization of the American library of the early 1800s came in the form of critical discussion; a projection of civic commitment that shaped the reclamation of physical space to establish the function of a collective knowledge and inquiry commons ${ }^{19}$.In Western Europe and the U.S, the "social" or "circulating" library that existed from late 17th to mid 18th century was a move toward the public access to texts as a means of supporting a connection to societal and leisurely literature, in addition to emphasizing moral and academic values ${ }^{20}$.

The distinction of the contemporary public library and its previous subscription-based models was the function of the library as a place to support the equitable dissemination of information as a free resource. Even more so, it can be considered that a new materiality that emerged in the construction of U.S. public libraries in middle of the 19th century underscored a presence of civic ideology as collective endeavor. Keeping in mind the metamorphosis of the book from a "devotional" object to the projection of book collections, historic research libraries, and the eventual flourishment of the permeable civic monuments that was the U.S library beginning in the mid 1800s; how is publicness and context resolved on the public library's social threshold ? The intent of this section was to place a lens on the book, as an object, and books, as collection. In the following section I present three cases of libraries, ranging from one of the earlier constructed public libraries in the U.S to a more recent version of library that still aligns to the concept of library as "civic" space.

\footnotetext{
${ }^{18}$ Kaufman, Paul. "The Community Library: A Chapter in English Social History." Transactions of the American Philosophical Society 57, no. 7 (1967): 1-67. doi:10.2307/1006043.

${ }^{19}$ Buschman, John, "Wayne A. Wiegand, Part of Our Lives: A People's History of the American Public Library," The Library Quarterly 86, no. 4 (October 2016): 476-478: https://doi.org/10.1086/688022

${ }^{20}$ Harris, Michael H. 1975. The Role of the Public Library in American Life : A Speculative Essay. Occasional Papers University of Illinois, Graduate School of Library Science, No. 117. Champaign: University of Illinois, Graduate School of Library Science; Bolton, Charles Knowles. American Library History. No. 1. American library association publishing board, 1911.
} 


\section{Library as Public-Context}

In this section, I draw on the theoretical concepts of space, public, and urban delineation to examine library as an architectural environment that takes into perspective the implicit modes by which concepts of space and geographical place can structure form and how these forms may engender dialogue as a result of social and visual values. The libraries selected in this study represent distinctive responses to the planes in which they are constructed. This places interpretation of a central or neighborhood library counterpart in terms of: (a) position in urban environment and (b) engagement of public through the visualization of a social institution.

In "Social Space", Henri Lefebvre introduces the concept of production as a delimited factor of the social relationships that lead to the development of environments. In review of Marx and Engels' theory on production, labor, and product, he aims to examine the condition that spatiality is less the attributes of and on which physical acts occur, but rather an emergence of the social factors and "interrelationships" that define $\mathrm{it}^{21}$. Lefebvre presents space through multiple situations, in one considering the case when space is physical "product", iterative and composed in such a manner that its social integrity can be obscured by its image or in the display of its representation ${ }^{22}$. He argues that space, in being "social", is not limited to the physical spatial organization that constructs geographical or territorial boundaries. If likened to the cartesian plane of objects and positions, social space is produced through the interactivity of social cases such that the boundaries imposed on a terrain are incongruent with the "continuity" of lived space ${ }^{23}$. Lefebvre's essay begs the question as to the extent by which people, the social delineators of space, contain agency in production and manipulation of constructed space. To unpack this issue, I will consider the implication of spatial production on the founding of the public library as a conceived structure of civic stimulation. As a point of departure I will primarily analyze Philadelphia’s Parkway Central Library, San Francisco’s North Beach Branch Library, and Barcelona's Jaume Fuster Library on the basis of their architectonic qualities in order identify public to context relationships.

\footnotetext{
${ }^{21}$ Lefebvre, Henri, and Donald Nicholson-Smith. The production of space. Vol. 142. Blackwell: Oxford, 1991: 69-70

${ }^{22}$ Ibid.: $74-76$

${ }^{23}$ Ibid.: 87
} 
Public libraries can be considered the two-way construct of manipulation and translation of architectural perception and the extent by which its production recall the ideologies on which they are instituted. In the United States, a typical characteristic of public library design in the mid 1800s has been the implementation of a central node that not only architecturally defines it claim within the urban context, but also performs as an essential link to a network of auxiliary branch libraries. The first case considers the emergence of the public library of Philadelphia in 1891. The intent of the Philadelphia Free Public Library system was to serve as a vital resource for the citizens of the city and operate under the novel concept of "Free Books for All"24. Beginning in 1903, Philadelphia utilized the Carnegie Public Library grant to establish 25 libraries which would help improve access to educational and informational material ${ }^{25}$. Just 172 years before the construction of the Carnegie libraries, Benjamin Franklin along with members of the Junto group founded one of the first subscription-lending libraries in the U.S, located in the historical Center City neighborhood of Philadelphia. ${ }^{26}$ This approach reflects the translation of produced public institution space based on a historical framework that regarded U.S libraries as the "custodians" of morality and civility ${ }^{27}$. As a first case study, the Philadelphia Parkway Library provides a basis in analyzing the spatial functions and contextual activation of contemporary public libraries in the U.S, particularly the North Beach Branch Library constructed in 2014.

\footnotetext{
24 "Digital Collections: About the Library-History," Free Library of Philadelphia, https:/ /libwww.freelibrary.org/digital/feature/75th/history

25 "Blog: The Carnegie Libraries of the Free Library: Past, Present, and Future," Free Library of Philadelphia, https:/ /libwww.freelibrary.org/blog/post/2271

26 "Benjamin Franklin's Junto Club and Lending Library of Philadelphia” National Humanities Center Resource Toolbox. http://nationalhumanitiescenter.org/pds/becomingamer/ideas/text4/juntolibrary.pdf. The Junto Club was an organized weekly group promoted by Benjamin Franklin to discuss the "improvement of citizens...and [form] better acquaintance with the general sentiments of the inhabitants"

${ }^{27}$ Harris, Michael H. 1975. The Role of the Public Library in American Life: A Speculative Essay. Occasional Papers University of Illinois, Graduate School of Library Science, No. 117. Champaign: University of Illinois, Graduate: 18
} 
Case A: The North Beach Branch Library | San Francisco, California

As a brief example in contextual signification, The North Beach Branch Library in San Francisco, CA by Leddy Maytum Stacy Architects anchors on the edge of the Columbus Avenue thoroughfare; a slash of continuous asphalt that takes the daily commuter from the massive brick buildings on Fisherman's Wharf to an abrupt stop at the concrete clad Transamerica Building in the Financial District. The distinction between historical operation of fisheries, manufacturing, and maritime production is at stark contrast to the high rise buildings that would soon cast shadow to a surrounding era of bygone brick buildings. The area of North Beach is characterized as having once been the epicentre for the mass movement of Italians to San Francisco's northernmost coastline ${ }^{28}$. In 1910, just thirty years after Italians held rising population numbers in the area and four years after the tragic 1906 San Francisco Earthquake and fires, the San Francisco Call regarded the North Beach neighborhood to be "one of the most prosperous parts of San Francisco". In their article, they report of the cultivated diversity of social and economic establishments in their community, including "manufacturing plants, warehouses, schoolhouses, and churches", as an optimistic indication of increased urban development ${ }^{29}$.

Planned in tangent to the development of the library, the Joe DiMaggio playground was part of an increased city-wide reaction to develop open and public spaces for San Franciscans ${ }^{30}$. The park and its proximity to the library can be considered a public space "anchor" that mediates highly interactive functions and public activity while simultaneously producing a scaled extension of the social component within the main ground floor of the library. Although the previous public library was on the same site as the playground, it was essentially a type of social island that was restricted by vehicular transit on its five sides. To expand the visual ratio of community space to the usual urban features of road and vehicle, the proposal dedicated a pedestrian thoroughfare where Mason Street was previously located. The renovation of the Joe

\footnotetext{
${ }^{28}$ Cinel, Dino. From Italy to San Francisco: The Immigrant Experience. Stanford University Press, 1982.

${ }^{29}$ Esmiol,A, "Populous District Enjoys Prosperity," San Francisco Call (San Francisco, CA), Jan. 22, 1910.

${ }^{30}$ San Francisco Recreation and Park. "Joe DiMaggio Playground Improvement Project”. SFRecPark. http://sfrecpark.org/project/joe-dimaggio-playground/
} 
DiMaggio Playground was planned for the entire main lot where the former library was constructed while allowing for the pedestrian road of Mason Street to act as a threshold between the library and the park.

The activation of site and collective outdoor environments are not only in reference to individual scale but serve as markers of social "continuity". In Columbus Avenue, parallel to the main entrance of the library, the site can be seen to slope downwards towards the northern Fisherman Wharf. The irregular aspect of the site recalls similar utilization of edge boundary as the Sentinel Tower and Flatiron building lying south of the North Beach neighborhood. On the north end of the building, its horizontal and vertical flatiron line perspective appear to sharply meet the horizontal edge of the succeeding buildings while forming a continuous sightline from the southernmost canopy edge of the building to its opposing north edge. In both of these situations, the North Beach Branch Library is a product perhaps less concerned with hyper-collectivity and more with the potential of localized "social" collectivity.

Composed of two levels, the ground floor of the library was designed to contain the majority of typical library elements of books and bookcases, chairs, tables, computers, and dedicated seating for varying activities. Rather than producing multiple floor levels of subdivided areas, spaces for a diverse public are grouped and designed to interact on the same level. Though the forming of a highly social open plan with increased access to technological resources, one of the primary objectives of the library was to construct supplementary space for a larger volume of books. What occurs is not a marginalization of the book, or the collection of book stacks solely as perimeter objects but as massed partitions of spatial functions. Thus, the book stack is placed throughout the spaces to separate or partially enclose areas while adding temporal transparency through the manipulation of the books. The second floor acts as auxiliary space, with a partially punctured floorplate that reveals the ground floor below. The program spaces for this level were limited to a secondary support space for library staff (i.e. "staff lounge") and the general public as in the case of the "community" room ${ }^{31}$. Each corner of the library (or the allocated children,

\footnotetext{
${ }^{31}$ Spur Project Review. North Beach Branch Library and Joe DiMaggio Playground." Spur. https://www.spur.org/sites/default/files/events_pdfs/04.06.11\%20The\%20New\%20North\%20Beach\%20Library \%20-\%20Marsha\%20Maytum.pdf
} 
teen, and adult area) has its own visual focal point that provides a wide-span window surface area connecting the area's edge to an external perspective of the surrounding environment.
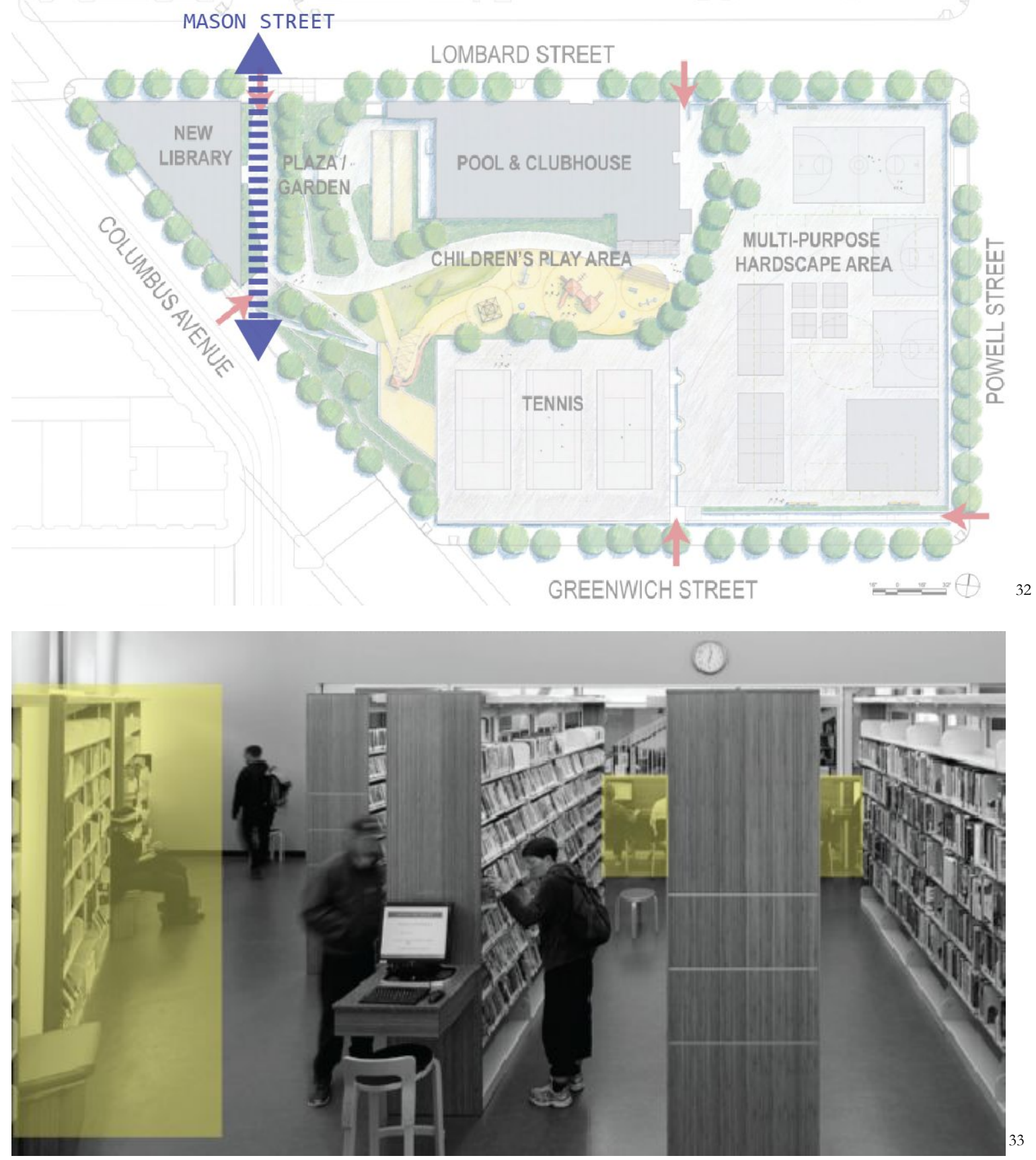

\footnotetext{
${ }^{32}$ Ibid.

33 Archdaily, 2014. North Beach Branch Library, Exterior.

https://www.archdaily.com/580711/north-beach-branch-library-lms-architects
} 
Chavez Cruz | 15
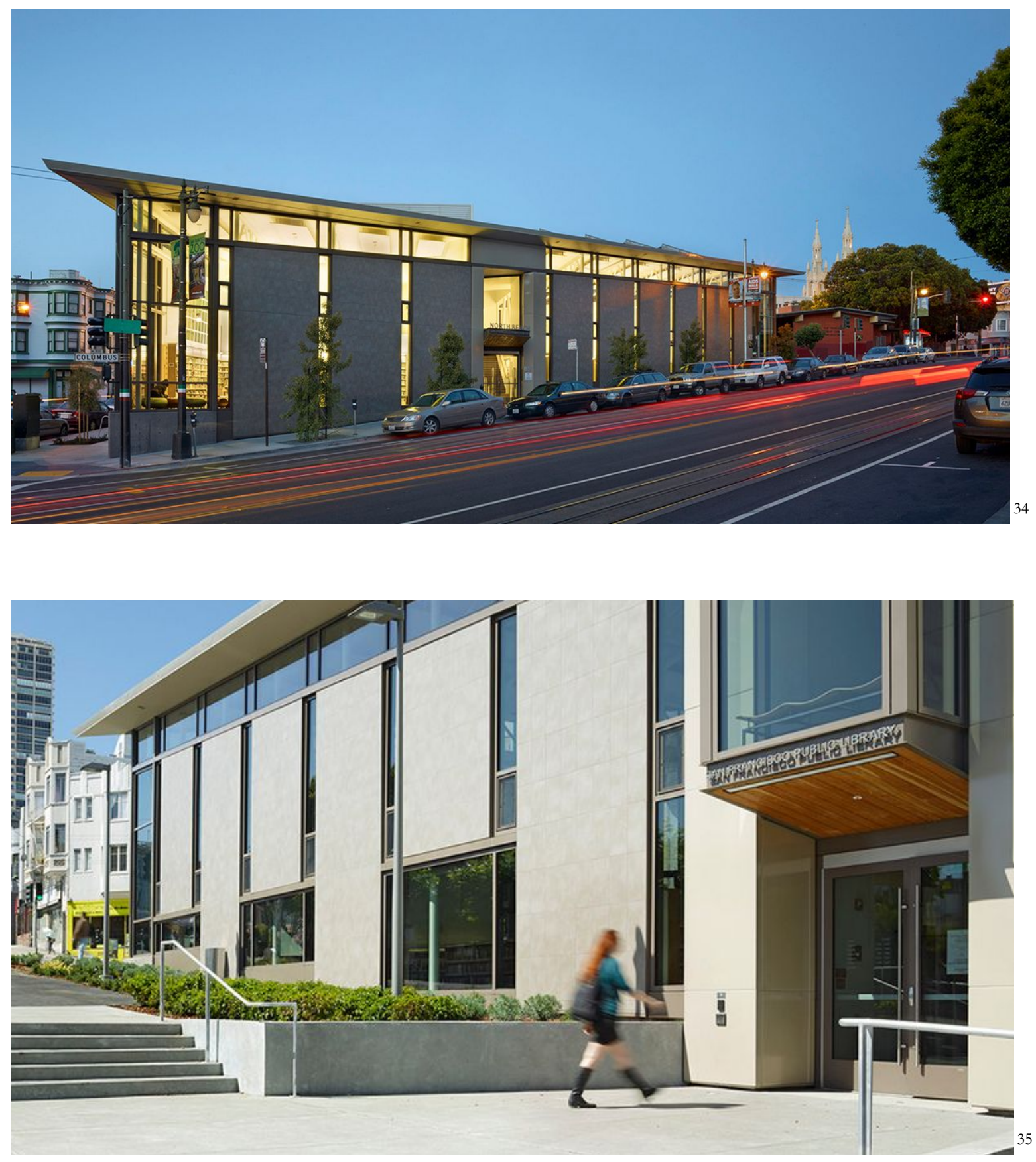

34 Ibid.

${ }^{35}$ Ibid. 
Case B: Parkway Central Library | Philadelphia, Pennsylvania

In the example of one of the nation's first public libraries, the Philadelphia Parkway Central Library was constructed in the central area of Philadelphia where the logics of the city's historical planning of its avenues, boulevards, and gridded pattern have transfigured social and spatial agency. In Philadelphia, the axial cut of space also known as the Benjamin Franklin Parkway was an operation into defining civic ideology through the ideations of the "City Beautiful Movement". The objective of the movement was to landscape a set of public organizations, governmental institutions, and monuments onto a city's central core to produce an effective urban plexus of public and social space ${ }^{36}$. The central library of Philadelphia is not atypical to the mode of the translation of Beaux-Arts techniques present in other U.S public libraries, namely that of the Boston Public Library-McKim Building and the central New York Public Library-Stephen A. Schwarzman Building.

However, it is The Role of the Public Library in American Life, that Michael H. Harris challenges the legitimacy of the concept of library as social institution of promoting "morality", common good and of being for "neutral" social continuation". He argues that the proponents of the establishment of the american library, in the context of aristocratic ideology, considered the construction of a knowledge space as a directive to the common people. This directive, was much more an opportunity to, as Harris quotes, "make men sober, righteous, conservative, patient, and devout" ${ }^{138}$. This brings us back to reflect on Lefebvre's address towards the condition that space and its continuous manifestation, as social function, do not occur in void or subject of speculative interpretation. Rather, "natural and urban space" can, as he defines, be enveloped in "directions" or parameters with the intent to delineate the actions or misactions of those who inhabit $\mathrm{it}^{39}$. He puts forth the situation of "monumentality" and attaches it to the concept of

\footnotetext{
${ }^{36}$ Peterson, Jon A. "The city beautiful movement: Forgotten origins and lost meanings." Journal of Urban History 2 , no. 4 (1976): 415-434.

${ }^{37}$ Harris, Michael H. 1975. The Role of the Public Library in American Life: A Speculative Essay. Occasional Papers University of Illinois, Graduate School of Library Science, No. 117. Champaign: University of Illinois, Graduate. ${ }^{38}$ Ibid.: 7

${ }^{39}$ Lefebvre, Henri, and Donald Nicholson-Smith. The production of space. Vol. 142. Blackwell: Oxford, $1991: 142$
} 

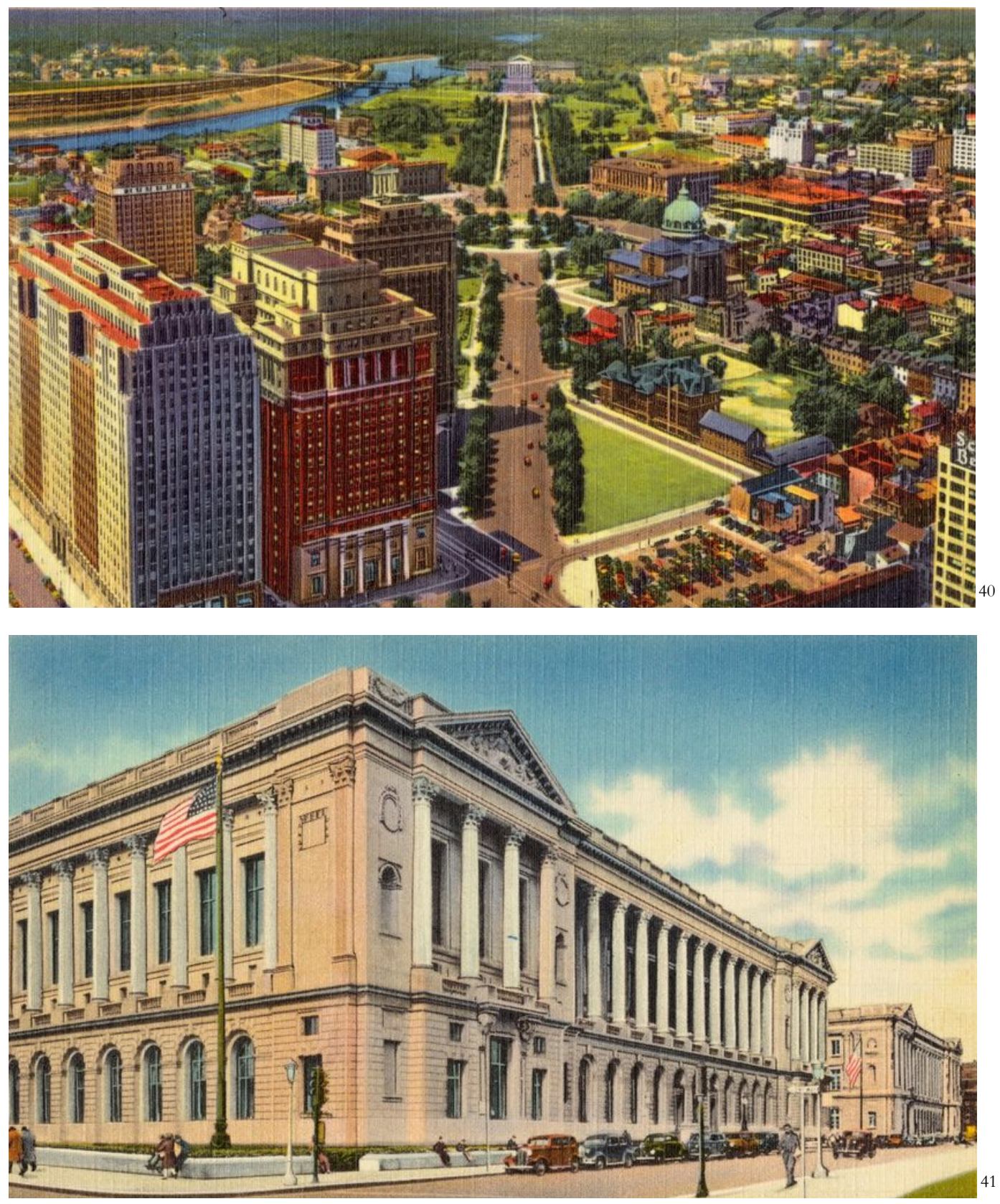

\footnotetext{
40 Ticknor Bros Inc. Bird's-eye view from City Hall, showing Benjamin Franklin Parkway, Pbiladelphia, Pa.. Postcard. From Boston Public Library Tichnor Brothers collection.

https://commons.wikimedia.org/wiki/File:Bird\%27s-eye_view_from_City_Hall,_showing_Benjamin_Franklin_Par kway,_Philadelphia,_Pa_(69401).jpg

${ }^{41}$ Ticknor Bros Inc. BFree library and municipal court, 20th Street and Benjamin Franklin Parkway, Pbiladelpbia, Pa... Postcard. From Boston Public Library Tichnor Brothers collection.

https://commons.wikimedia.org/wiki/File:Free_library_and_municipal_court,_20th_Street_and_Benjamin_Frankli
} 
"reading" space, where the intent of generating "direction" as "message" has the capacity to conduce ideology and assign socio-political interpretability ${ }^{42}$

In short, it is possible to interpret that the public library may have not been a means wherein the the public would explicitly exercise social agency but rather where the people would be the moral product of the "civilizing forces". Harris considers the political events from 1930's onward, that caused a reconsideration of the public library's role, lead to the social function of the library not as a messenger but as a solace of "neutral" perspective; of an impartiality and equality that the community needed in order to conduct their own purpose. With this, he concludes that the public library has in some forms, through its iterations and systematic reassessment (from civic reformer to silent "bystander"), misplaced their "purpose" as institution 43.

In a similar historical discourse, Robert V. Williams studies the underlying social and political frameworks in the development of public libraries ${ }^{44}$. In The Public Library as the Dependent Variable, he works through four theoretical factors as potential basis for the emergence of the library in the public realm: (A) "the social conditions theory" that considers the public library as a formation of multiple constructed social or societal values, which he remarks, have yet to be evidenced in the production of public libraries ${ }^{45}$. Williams presents a review of literature surrounding the confluences of public library development as contained in cases of overall education and "financial [or] economic" sustainability within a community, "urbanization", and "political conditions" 46 . (B) "the democratic tradition theory" where he presents a prominent perception within library history, namely that their manifestation was to communicate an ideal

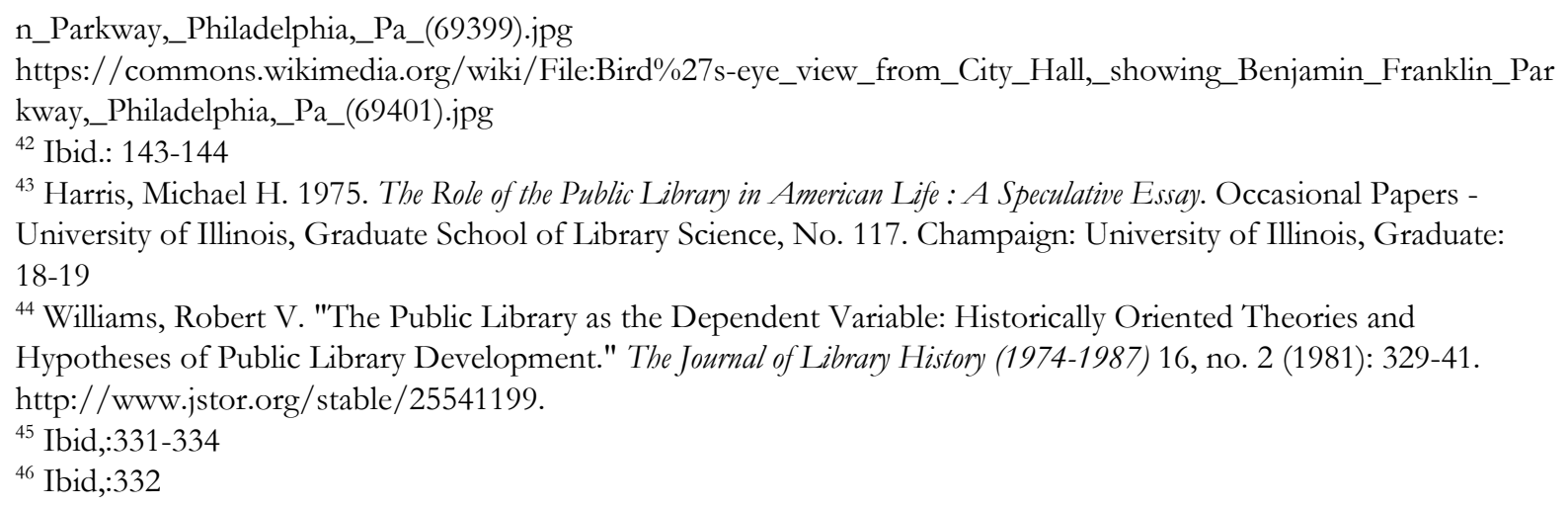


collective $^{47}$. This collective would function and thrive on the basis of their conformance to civic and democratic values. $(C)$ "the social control theory" as an approach that reflects the social aspect of library as not only the production of an idealized representation for public improvement but as a work of aristocratic principles ${ }^{48}$. In his commentary, he cites Harris, Garrison, and McLeod to demonstrate the historical instances where the development of libraries may have been considered to be contingent on the "elite" "control[ling] social change". (D) "Influences of Libraries and Librarians" is presented as an alternative position where the library is capable of affecting its own production rather depend on social and political factors. In his paper, William provides a critical portrait of the phenomena of sociological, power and political factors that may contribute basis for library development. Nevertheless, his general claim is that the outlined theories have yet to be rigorously attached to situational studies, so that to consider any factor as causation of "development" would be unbiased generalization in terms of its potential usefulness as a historical perspective ${ }^{49}$.

Though Williams delineations may detract on the important qualities of social and political spatial determination, it offers a critical viewpoint on which to assess the modes in which the "social variables" may affect the production of "public library". In the process of considering library as public-context, I am principally concerned with the evaluation of the external and internal spatial conditions for signs of social representation and their relation to constructed signifiers.

The Philadelphia Central Library remains original to its 1927 construction by architects Julian Francis Abele and the Horace Trumbauer Company, with its principal building entrance forming the historical interface between public and visitor functions. Figure 1a presents a South elevation of the library's original design concept with the present archetypal "plinth", in the form of an elongated sidewalk step and three additional steps that gradually act as a threshold dividing the external public and the internal collective domain. The North facade, Figure 1b, was designed to be a similar representation of the main entrance without the rounded arch inset

\footnotetext{
${ }^{47}$ Ibid,:334-335

${ }^{48}$ Ibid,:335-338

${ }^{49}$ Ibid,:339-340
} 
windows or the three entry points that form part of the main South entrances. As a central-type library, its spatial organization varies and has been under gradual transformation to take its 20th century floor plans into an age of visual transparency, social collectivity, and increased technology demands. A revised version of the original floor plan demonstrates the changing nature of library space from what was previously a set of reading, literature, and group specific areas. Two distinct and modern modifications to the library's ground plan is the addition of a “Teen Center" where the "Newspaper Room" was located and a "Business Resource and Innovation Center" that once formed the "Deck of Stack" room sitting just below two levels of principle book stacks. Essential areas such as washrooms, storage, book stacks, stairs, and lockers, were concentrated in the center or upper center of the plan while leaving the perimeter zone to programmed rooms. The original design, which did not provide spatial meshing opportunities, separated each program into its own area constructed as individual containers of people and objects. Under the original socio-cultural intentions of the library, the books were not considered to be a mass set of knowledge objects that could be independently perused, but instead, book retrieval occurred by qualified individuals who worked in the library and checked books to patrons under a process that functioned through 11 steps. In this scenario the only agency a Philadelphian reader had over the type of knowledge they chose was in the ability to browse book catalogues to select a book that could not be read or skimmed over before interfacing with a librarian.

The second floor was designed to accommodate higher levels of seating than in the smaller corner and edge rooms found on the ground and first floors. The central spaces were the second floor Pepper Hall with a grand staircase leading to it and a "Main Reading Room" with adjacent corner "Special Reading" rooms. These reading spaces extended onto the third floor so that in sectional view, they read as expansive areas capable of bringing in daylight from multiple surface sides (e.g. walls and ceilings) to illuminate the rooms for the task of reading. Display cases and bookcases were held in the long reading areas of "Pepper Hall" and the "Main Reading Room", however, the primary function of the space was to serve as seating area. The main book collection zone still remained a part of the designed multi-level stack rooms. In the 
current second floor plan, the "Main Reading Room" and "Pepper Hall" was transformed into the book stack compartments present in much of the libraries today. Such that rather than the books being hidden from view, they now reflect the individual practice of searching and collecting books. After awarding Moshe Safdie Architects the Parkway Central Library renovation project in 2004, one of the first implementations of spatial reconfiguration that took place within the library's interior spaces was the Philbrick Hall, previously the main periodical room located on the first floor. The renovation can be considered to emphasize a similar space activation with low to medium height bookstacks as was noted in the main interior move of San Francisco's North Beach Branch Library. In much the same manner, the bookstacks act to partition and separate levels of activities without losing interconnectivity between the spaces as may be the case in solid partition walls. 


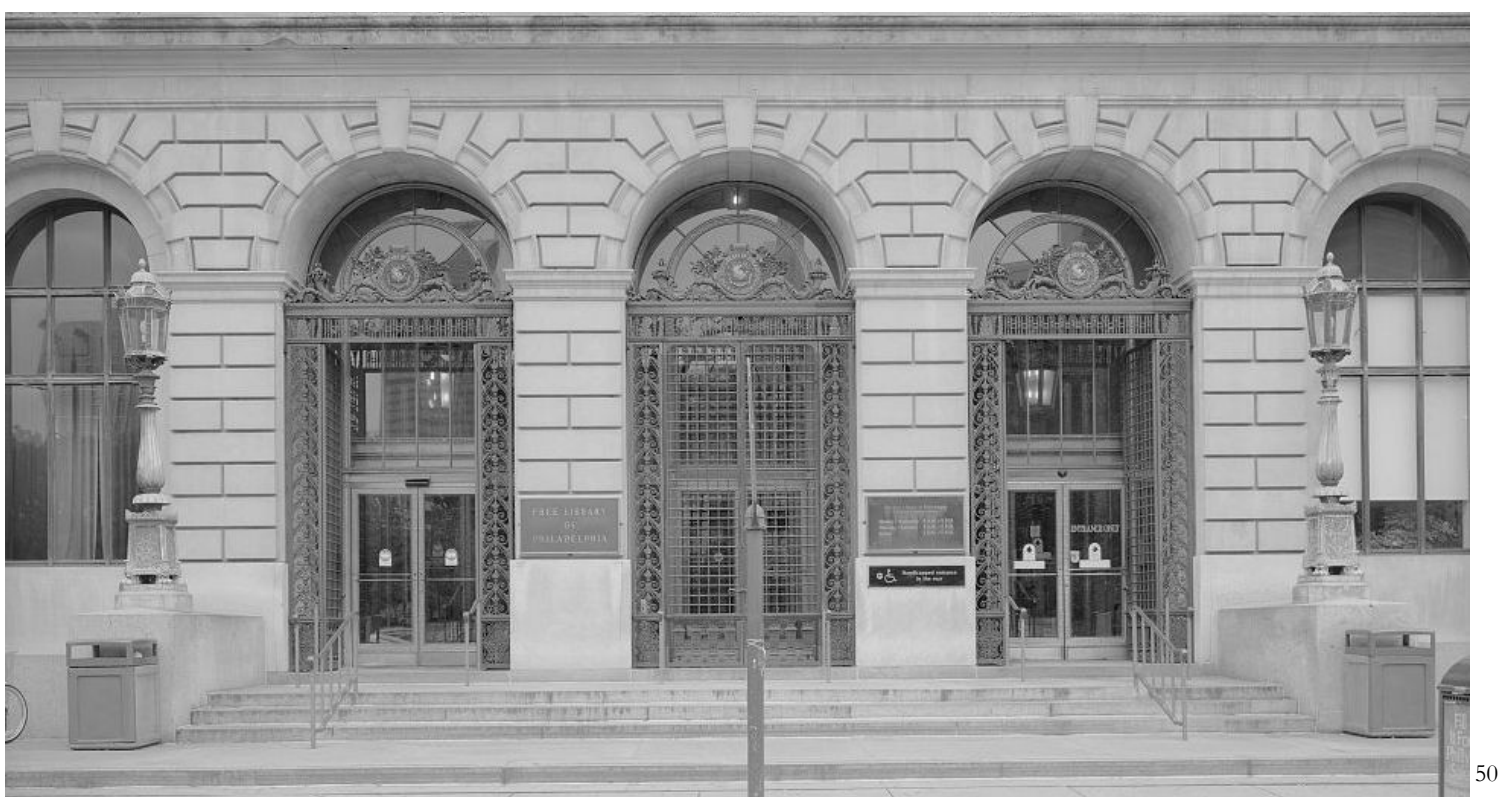

\section{Fig. 1a}

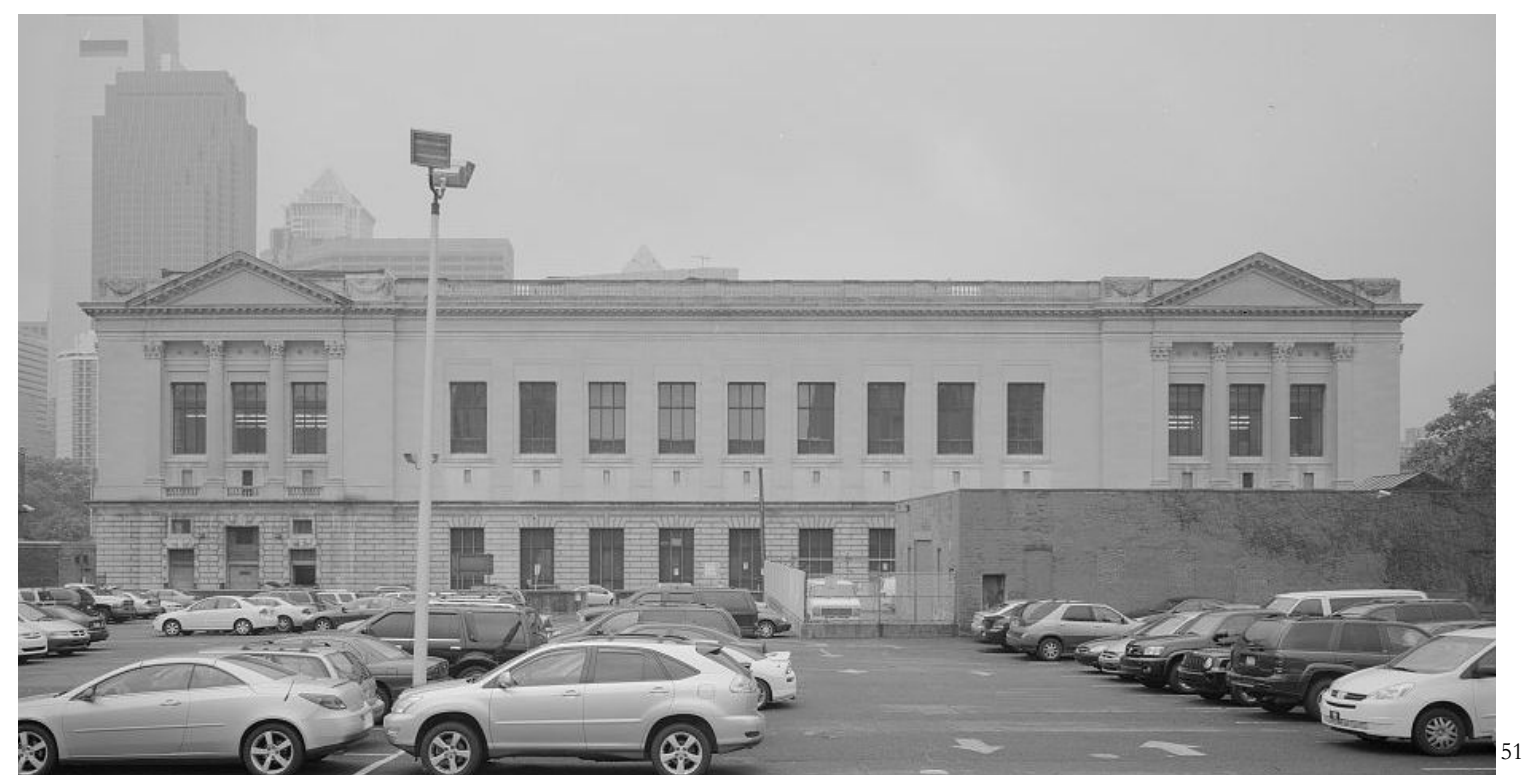

Fig. 1b

${ }^{50}$ Elliott, Joseph. ELEVATION OF MAIN ENTRANCE, SOUTH FRONT - Free Library of Philadelphia, Central Library, 1901 Vine Street, Philadelphia, Philadelphia County, PA. Photograph. From Library of Congress Prints and Photographs Division, Historic American Buildings Survey.

http://www.loc.gov/pictures/item/pa4067.photos.573839p/

${ }^{51}$ Elliott, Joseph. NORTH REAR ELEVATION - Free Library of Philadelphia, Central Library, 1901 Vine Street, Philadelphia, Philadelphia County, PA. Photograph. From Library of Congress Prints and Photographs Division, Historic American Buildings Survey. http://www.loc.gov/pictures/item/pa4067.photos.573835p/ 


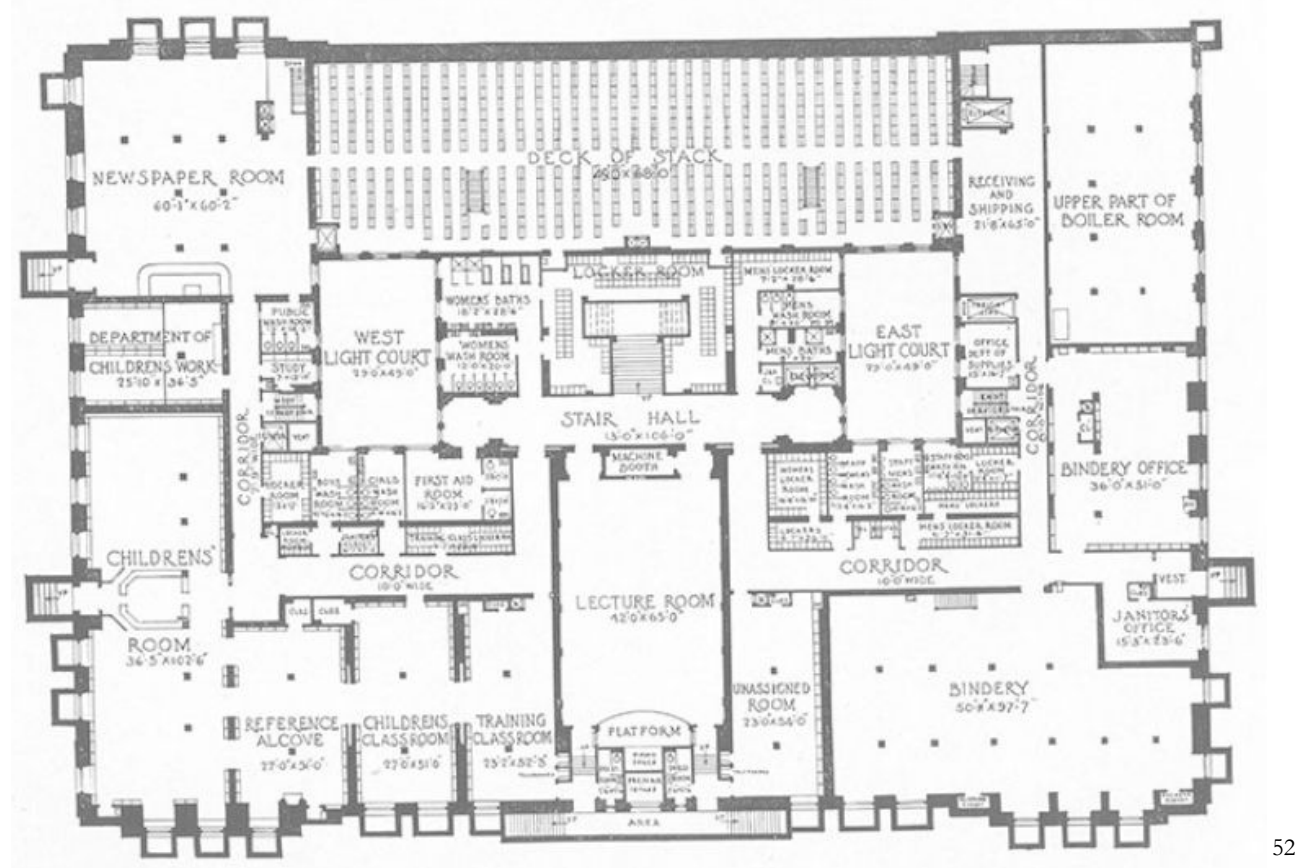

Fig. 1c

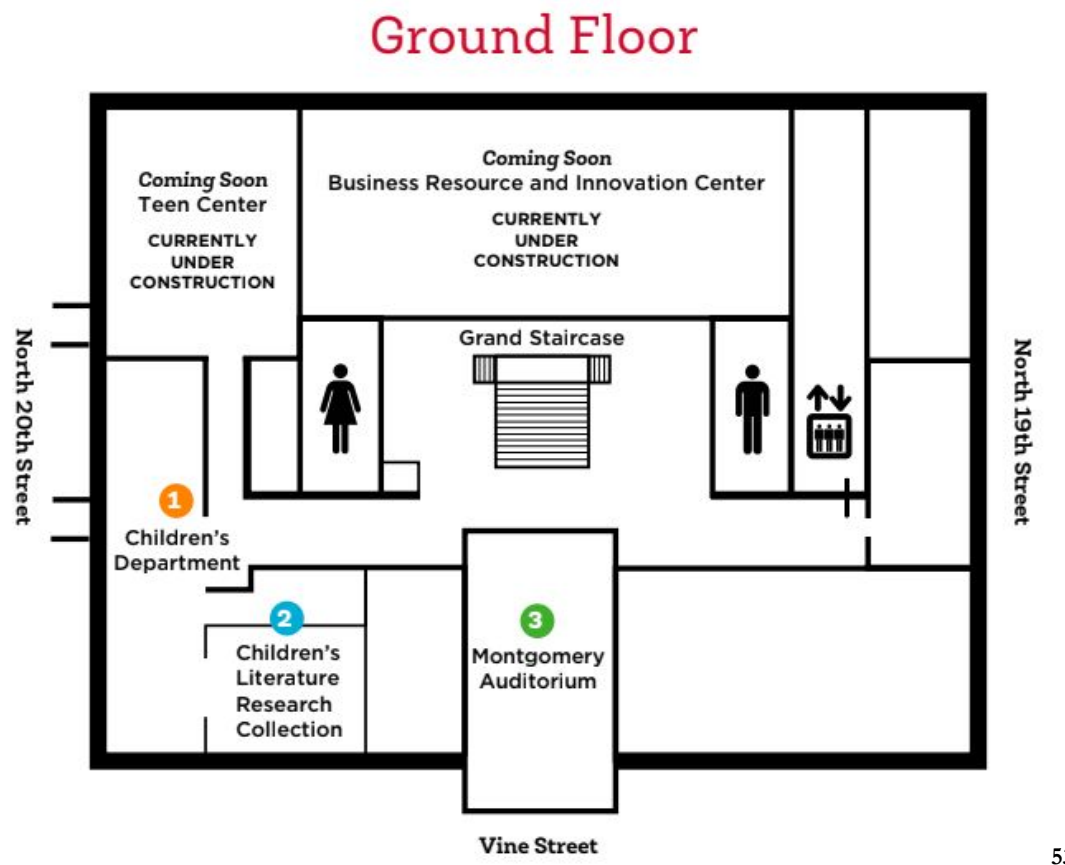

Fig. 1d

52 Ground floor plan, steel-frame version of the Central Library of the Free Library of Philadelphia, 1922. Floor Plans. Free Library of Philadelphia: Philadelphia, PA. https://libwww.freelibrary.org/digital/item/2772.

53 Free Library of Philadelphia. "Parkway Central Booklet."

https://drive.google.com/file/d/0By18SiaBMoq3a2N0d0Y1Uk5zSzQ/view 


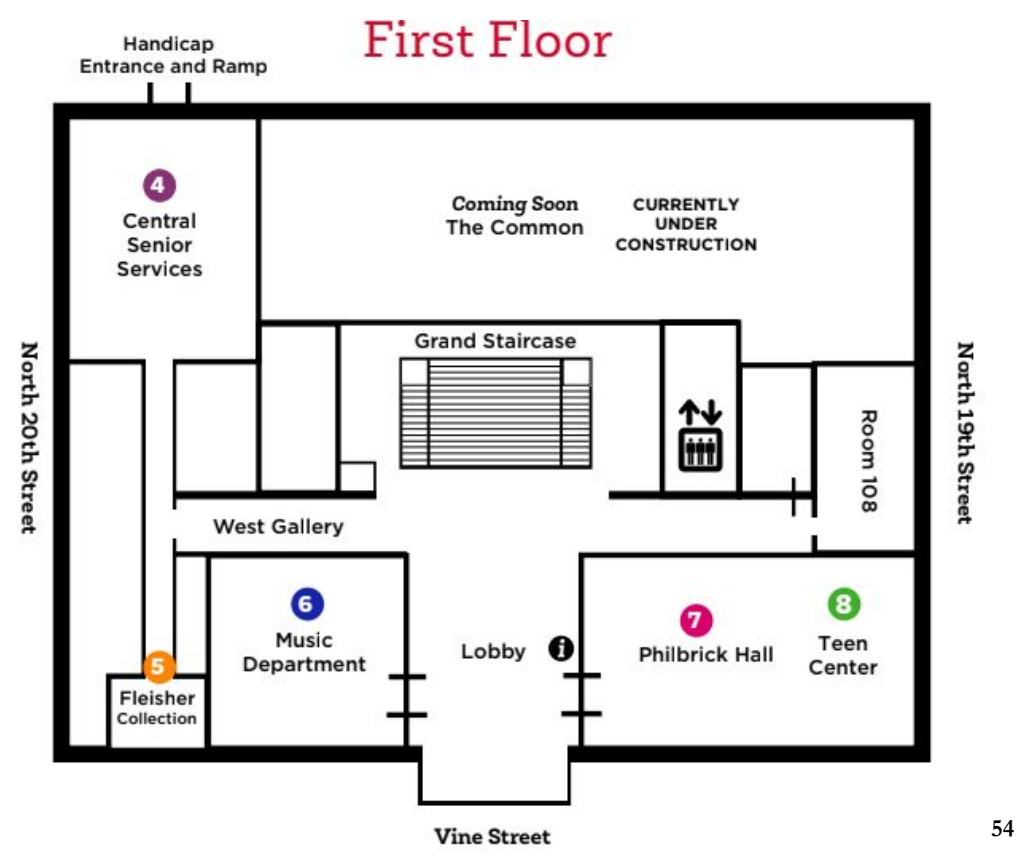

Fig. 1e

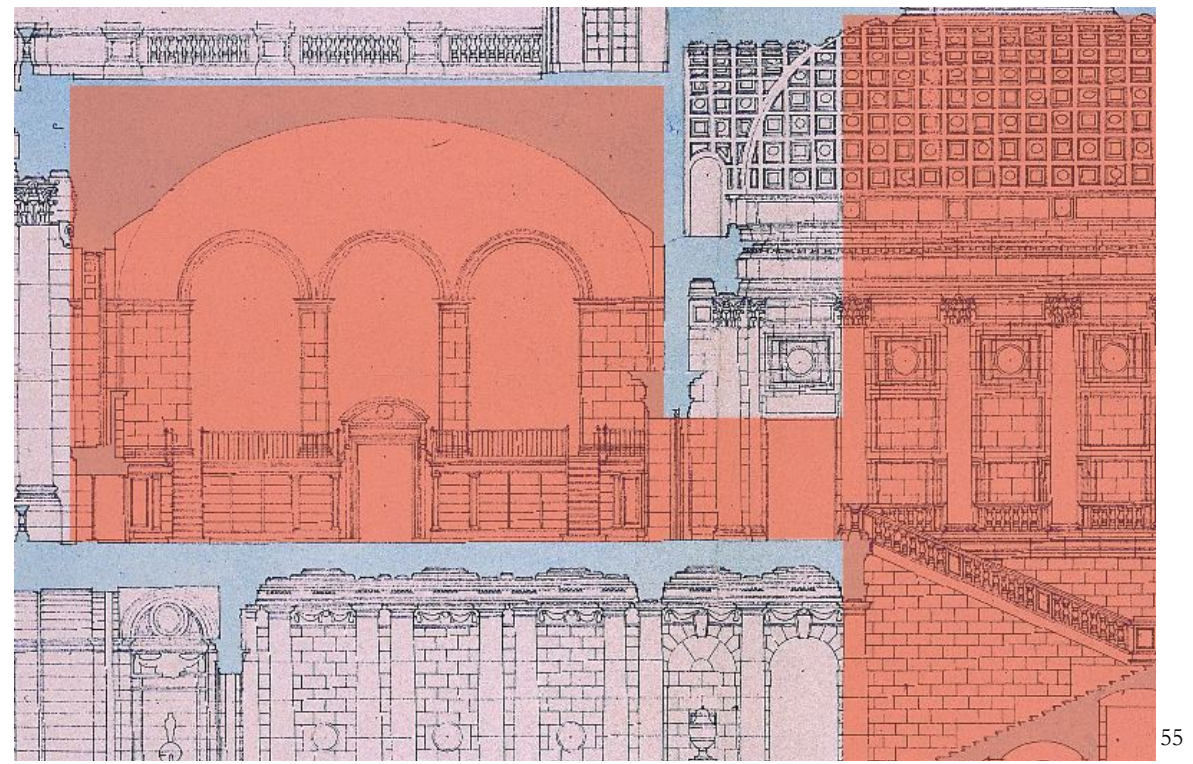

Fig. If

\footnotetext{
${ }^{54}$ Ibid.

${ }^{55}$ Transverse section. Elevations. Free Library of Philadelphia: Philadelphia, PA.

https://libwww.freelibrary.org/digital/item/711. Pepper Hall highlighted in red (leftmost), this section exhbits the changes in scale from the two floors high space of Pepper Hall, to the compressed scale entrance, and the spatial extension of the grand staircase.
} 


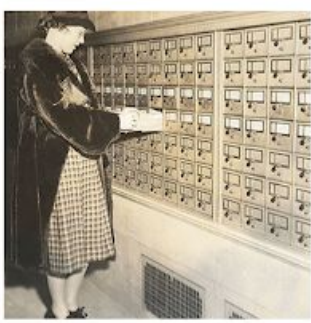

Step 1 The patron searches the card catalog in the Central Library of the Free L.ibrary of Philadelphia for the call number of the book which she is interested in this case Edward Everett Hale's Franklin in France

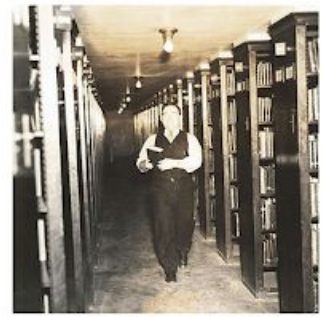

Step 4. The runner retrieves the book from the shelves takes it to the central station on that floor of the Bookstacks in the Central Library of the Free L.ibrary of Philadelphia

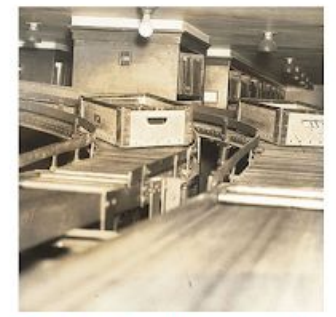

Step 7 . The box with the requested book winds its way through the Bookstacks toward the Main Readin Room of the Central Library of the Free Library of Philadelphia

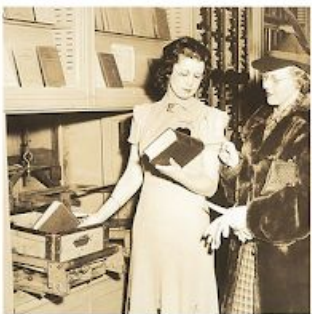

Step 10. In the Main Reading Room of the Central Library of the Free L.brary of Philadelphia, a library staff member retrieves the requested book from the dumbwaiter and hands it to patron

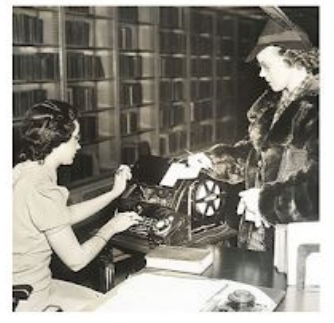

Step 2. After finding the call number in the card catalog for a book the patron wishes to borrow, she requests the book from the library staff member in the Main Reading Room in the Central Library of the Free Library of Philadelphia

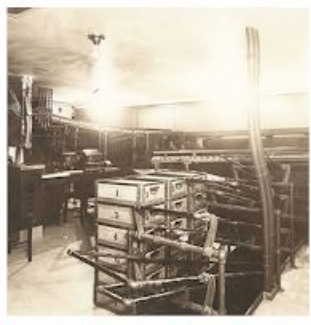

Step 5 The book is taken to a central station in the Bookstacks of the Central Library of the Free Library of Philadelphia where it will begin its automated journey on the conveyor system to the Main Reading Room

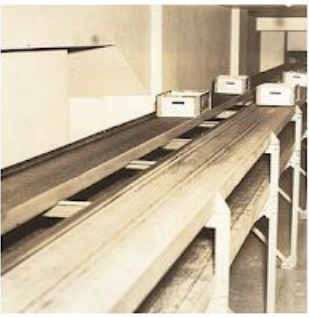

Step 8 . Eventually the box with the requested book makes its way to the sixth level of the Bookstacks and across the first mezzanine floor to point directly under the Main Reading Room of the Central L.brary of the Free Library of Philadelphia

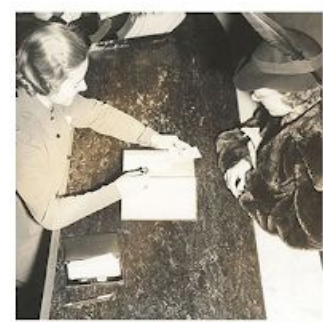

Step II. In the Main Reading Room of the Central Library of the Free

Library of Philadelphia, a member of the library staff charges the

requested book to the patron's

account. The entire process took only two to four minutes

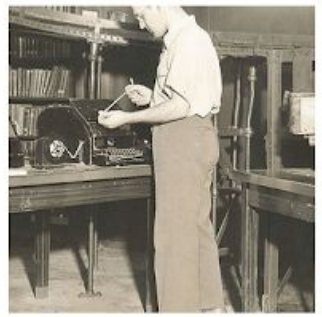

Step 3 The call number of the book requested is received on the teletyp receiver on the correct floor in the Bookstacks in the Central Library of the Free Library of Philadelphia A runner is dispatched to retrieve the book from its place on the shelf

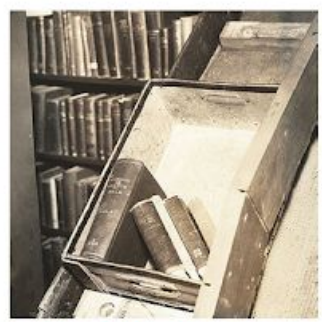

Step 6 . The book is placed in a bo which will be transported to the Main Reading Room of the Central Library of the Free Library of Philadelphi

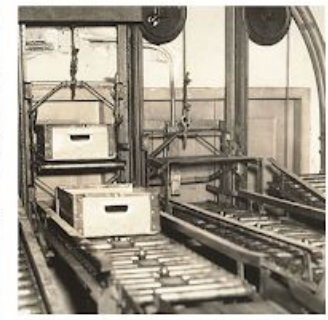

Step 9 . The box with the requested book is raised by a dumbwaiter from the first mezzanine level to the Main Reading Room of the Central Library of the Free Library of Philadelphia 


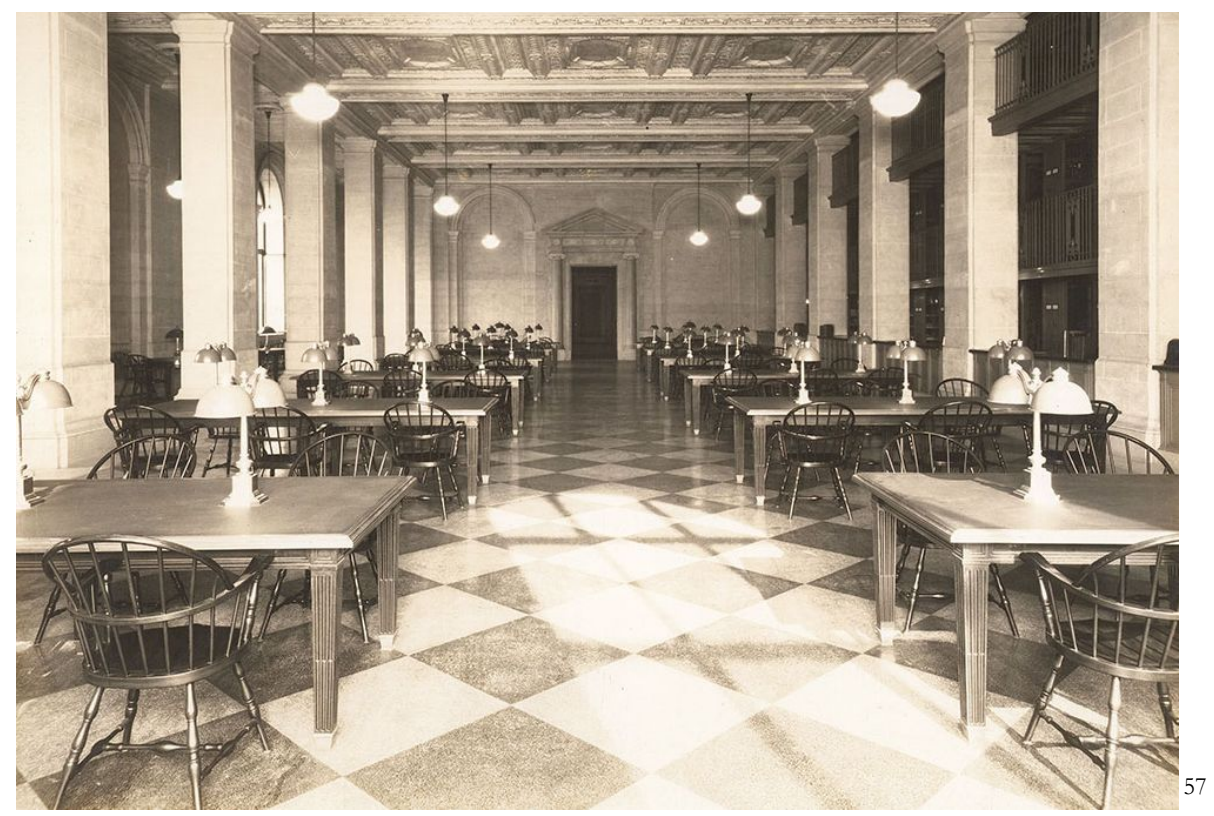

Fig. 1h

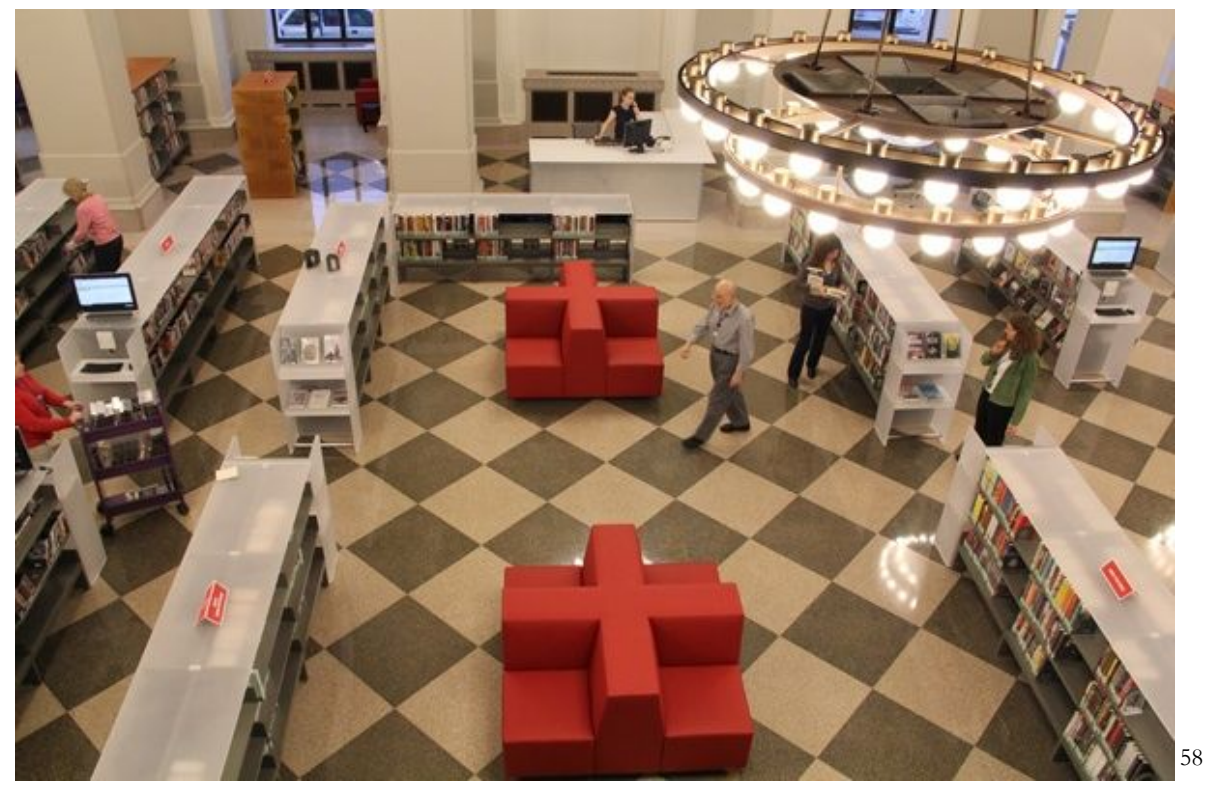

Fig. 1i

56 Step 1-11.Photographic Prints. Free Library of Philadelphia: Philadelphia, PA. https:/ /libwww.freelibrary.org/digital/item/51. (accessed Mar 24, 2018)

${ }^{57}$ Periodical Room, now Philbrick Popular Library of the Free Library of Philadelphia. Photographic Prints. https://libwww.freelibrary.org/digital/item/655

58 WHYY. "New edition of Philbrick Hall lends more space to Free Library" https://whyy.org/articles/29pclibrary/ 
Case C: Jaume Fuster Library | Barcelona, Spain

The Jaume Fuster Library in Barcelona, Spain, is situated between the Ronda del Mig or the "middle highway" and the immediate residential structures bordering its overlapping planes. It sits at the edge of the Gracia neighborhood, that was from 1950 to 1897, an independent municipality separate from the city of Barcelona ${ }^{59}$. The section of evolving greenscape just east of the library is a development plan of the city of Barcelona to present its inhabitants with an expansive pedestrian accessway that counteracts the effects of increasing vehicle transit and the rise of low-density environments ${ }^{60}$. The Plaça de Lesseps accentuates the utilization of its landscape as collective public space while also adding to the vision of social space in the playground and plaza surrounding the front of the public library. The buildings on the backside of the library form the typical urban mass that is iterated among neighborhoods throughout Barcelona. The organization of shops, eateries, bars, and public services occur on the ground level of the structures leaving the remaining upper floors for residential units; due to spatial constraints, any high capacity parking occurs underground. On the corner of streets Avinguda de Vallcarca and Pl. de Lesseps and facing the entrance of the library is the public school Rius i Taulet constructed in 1957.

In their design, Josep Llinas and Joan Vera describe that the objective of the library was to provide a social "continuation" of perceived public space, extending from Plaça de Lesseps to the plaza on the site:

"In the first case, the aim was to merge the volume of the library with that of the buildings to the rear...in the second case, the creation of the green belt, to the north of

\footnotetext{
59 Jordi Serchs i Serra. "Guia de l'Arxiu Municipal del Districte de Gràcia," Ajuntament de Barcelona Arxiu Municipal de Barcelona (1997): 5-7.

${ }^{60}$ Meritxell Huguet Gil, “ PLAZA LESSEPS: De Els Josepets a la Jaume Fuster, evolución de una plaza, y de la concepción de espacio urbano (Lesseps Plaza: From Josepets to Jaume Fuster, Evolution of a Plaza and its Conception)," Master and Theory in Practice of Architecture Projects, Politechnic University of Catalonia. 2010
} 
Plaça Lesseps is seen as a public thoroughfare that expresses and adapts to the singular topography that accommodates this part of the city"61

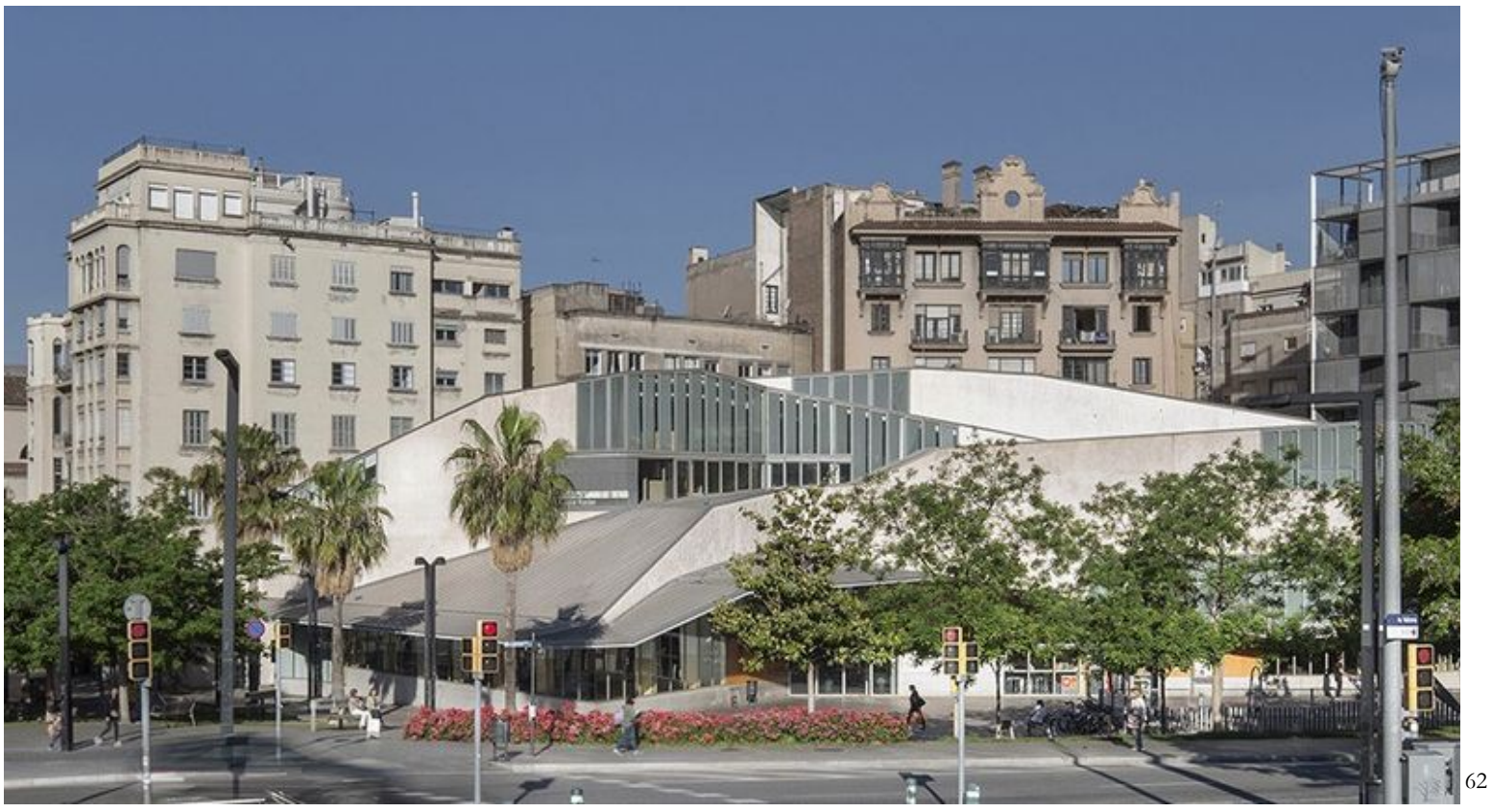

\section{Fig. 2a}

\footnotetext{
${ }^{61}$ Osarte, Xavier. "Bliblioteca Jaume Fuster (Jaume Fuster Library) : Josep Llinas." Quaderns d'arquitectura i Urbanisme, 2005; No. 248, p. 46-63.

62 Marek Jarosz Photo, 2014. Jaume Fuster Library, Barcelona,. http://marekjarosz.allyou.net/8572817/jaume-fuster-library
} 


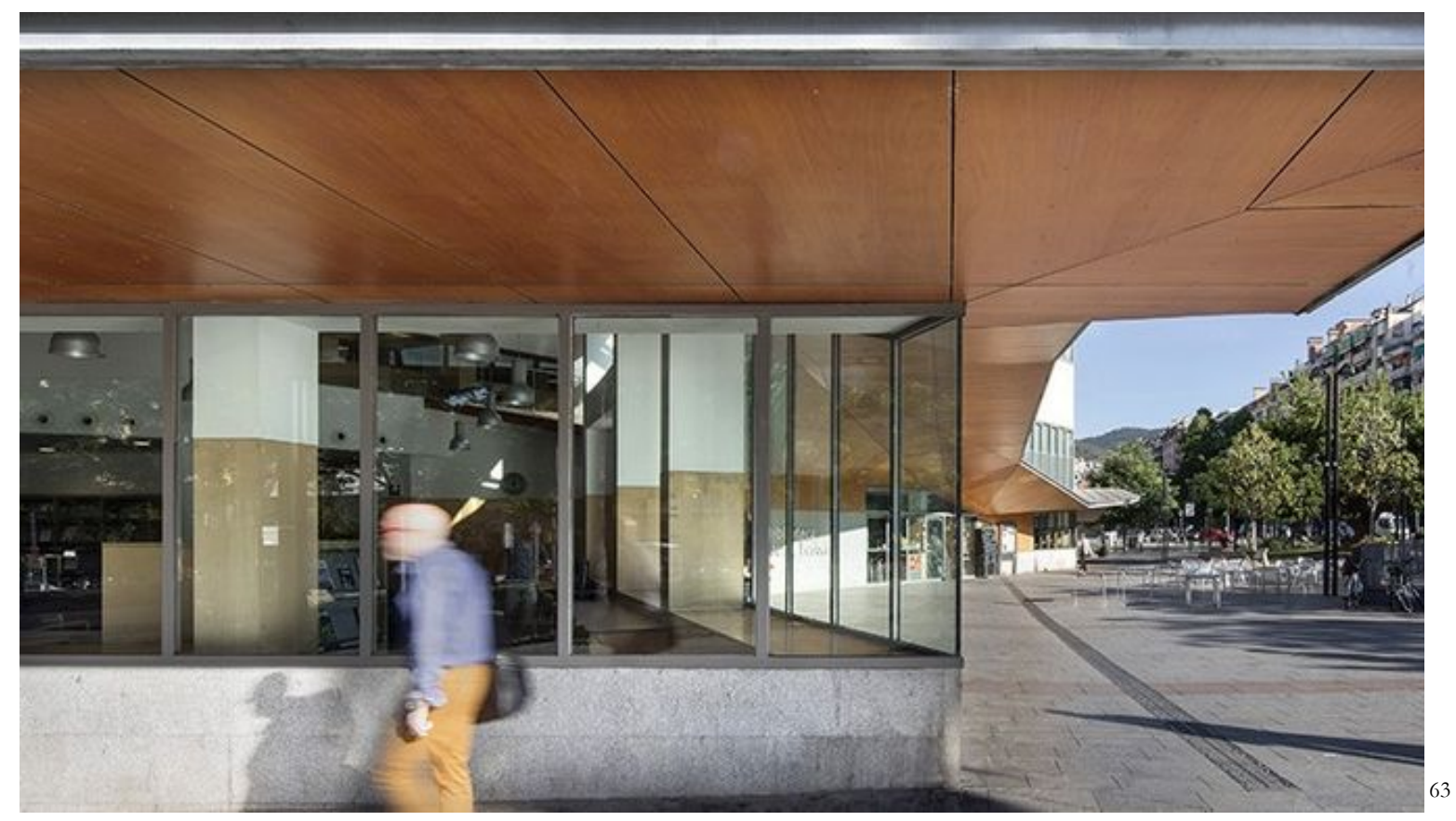

\section{Fig. $2 b$}

What Llinas refers to in his assertion of "singular topography" is the opportunity for the building to capture the underlying landform boundary or the "condition of a mountain-city border" of the Collserola mountain range. As such, it is visible from the overlapping and sloping of vertical and horizontal planes, in this case of facade and and roof, that the interlayering of natural context somewhat decides the articulation of non orthogonal surfaces (see Figure 2a). In relation to built context, the development of walls and roofs act to open and envelope as part of the environment.

This artificial mountainscape proposed by the library's architecture appear to engrain within the urban landscape as an artificial landform or social mountain. This form, unlike the natural counterpart becomes physically attainable space, it can be inhabited, and produced to encase the social functions of its visitors. In terms of its resources, social and collective zones, the library provides the ability for an increasingly private or individualized production of space by its user. It is possible then, through a vertical movement, to reach levels of "intimate" inquiry, study, reading while leaving the indoor social space on ground level.

\footnotetext{
${ }^{63}$ Ibid.
} 
Richard Williams, in Architecture and Visual Culture presents the theory of "architecture as urban experience" in highlighting the individual reaction to the effects of urban processes ${ }^{64}$. He considers that the "urban experience" exhibits the function of inducing a similar aspect of social production that is highlighted in Lefebvre's work. What occurs in the form of production is reiterated in Walter Benjamin's work on the "flaneur" as "consumer" and the social construction of space as contextual "phantasmagoria" Library, glazed surfaces, Figure 2b (and plan of ground floor in Figure 2c), have been situated to frame the social interior of the ground floor reading room and cafe area. A similar idea to the Paris arcades of Benjamin's work on can be applied to discuss how these windows can serve to interpret the interior of the library's ground floor as a type of method of engaging with visual consumption. If the "flaneur" or the passerby who engages with the exterior public space also interacts with the production of spatial consumption occuring in its interior, then there seems to be no necessity in partaking as a physical patron. Rather, what view Benjamin offers in the consumer behavior of the "flaneur" is a vitrine typology of exhibited social space. In sum, the interior users of their space, the "intelligentsia surrender[s] itself to the market". What exterior to interior connections occur on the first floor, appear to be the inverse as the patron inhabits the second level spaces. In this case, the exterior does not infringe or partake in the interior conditions of social space due to it not being to the level of the exterior public. Rather the interior public participant or patron is able to engage and consume the image of the neighborhood through floor to ceiling windows situated in study areas as well as common zones. Figure 2e demonstrates the long seating object located on the second floor, that can be utilized to appreciate the wrap around views. The metal corrugated roof itself acts as an artificial ground on which the extension of the surrounding Gracia landscape is visually constructed upon.

\footnotetext{
${ }^{64}$ Williams, Richard. "Architecture and Visual Culture." Exploring Visual Culture: Definitions, Concepts, Contexts (2005): 102-116.

65 Benjamin, Walter. "Paris: capital of the nineteenth century." Perspecta (1969): 165-172.
} 


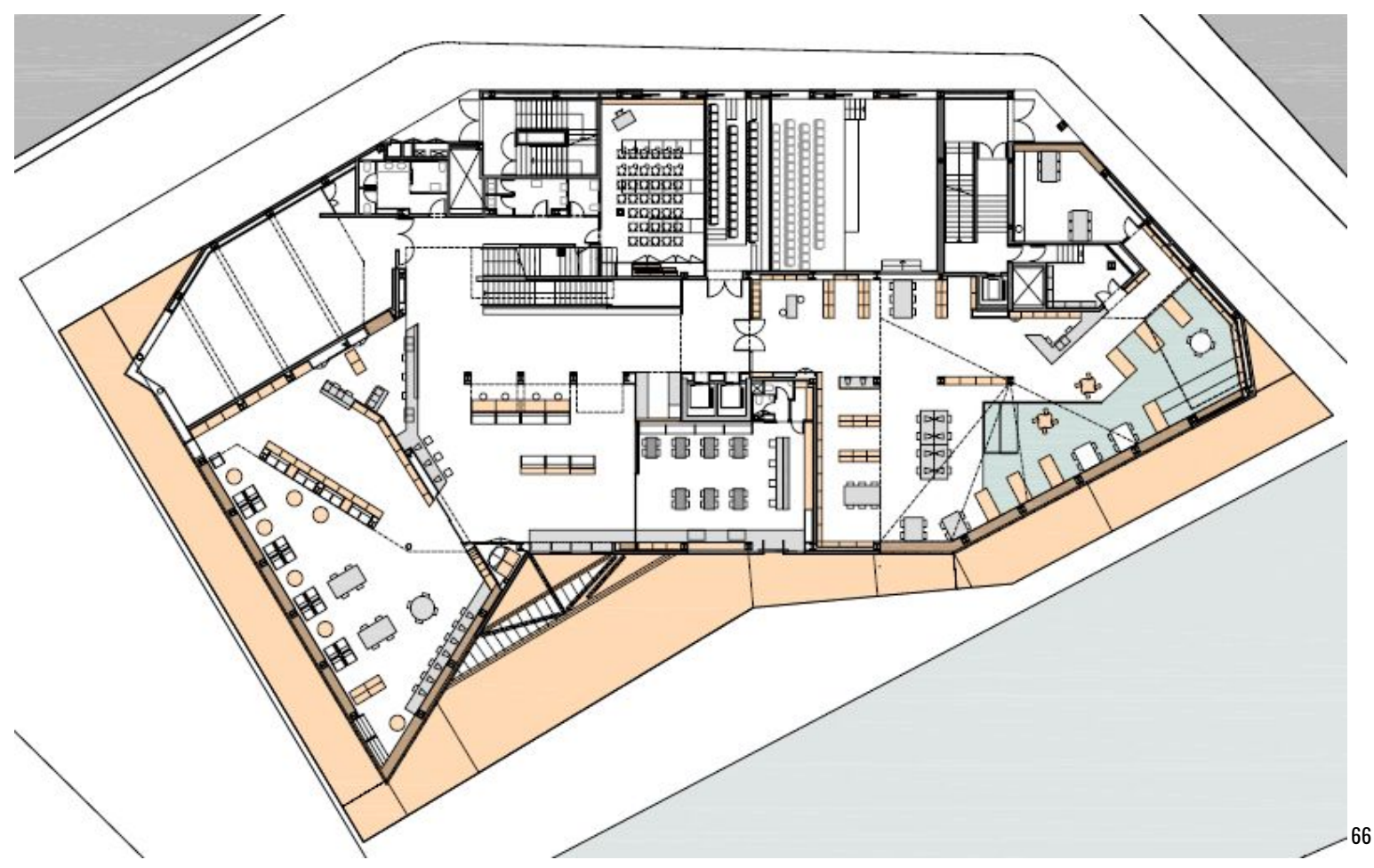

Fig. 2c

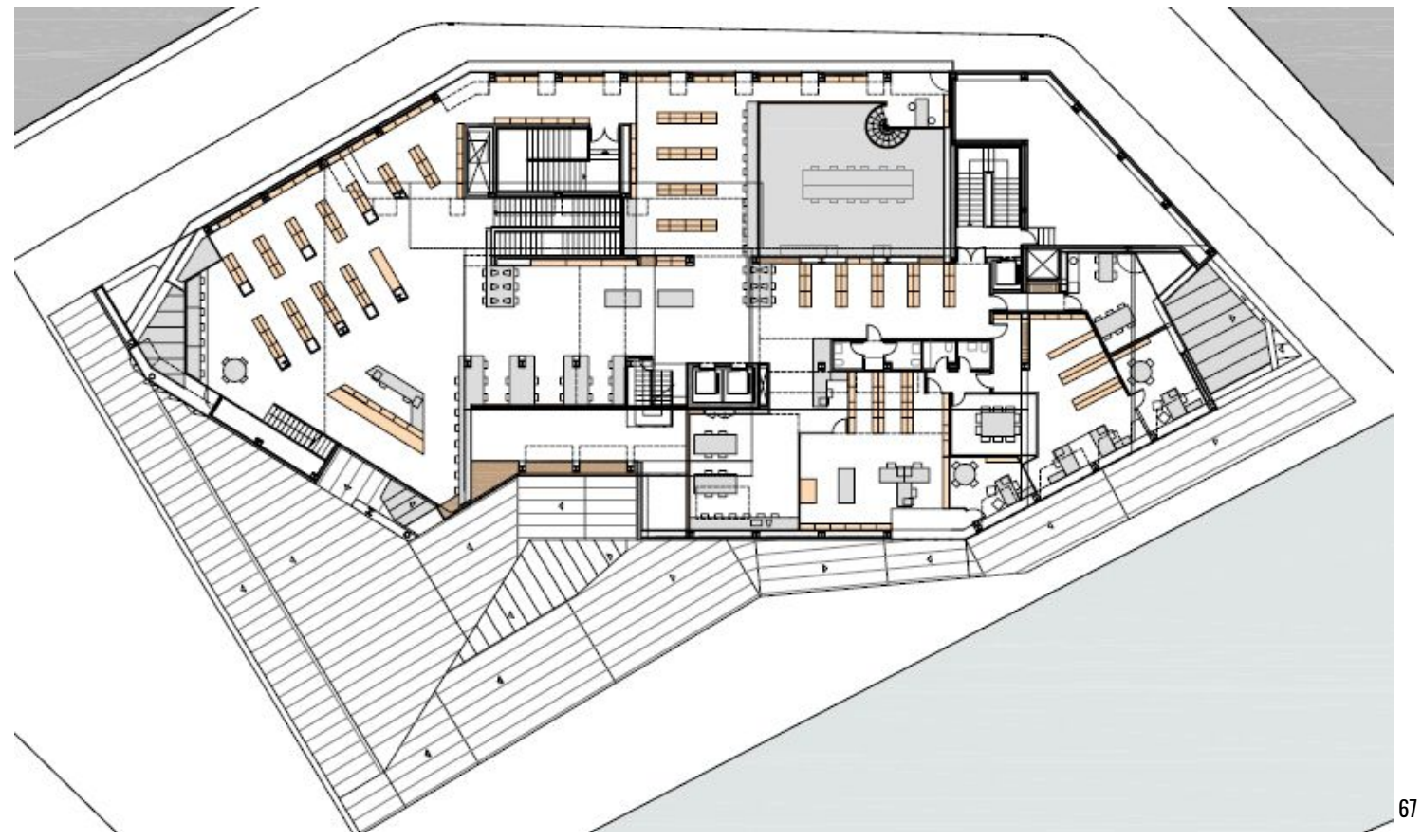

${ }^{66}$ Carlos Cachon Grafico, 2014. Biblioteca Jaume Fuster [.] Barcelona.

http://carloscachongrafico.blogspot.com/2011/11/biblioteca-jaume-fuster-barcelona.html ${ }^{67}$ Ibid. 


\section{Fig. 2d}

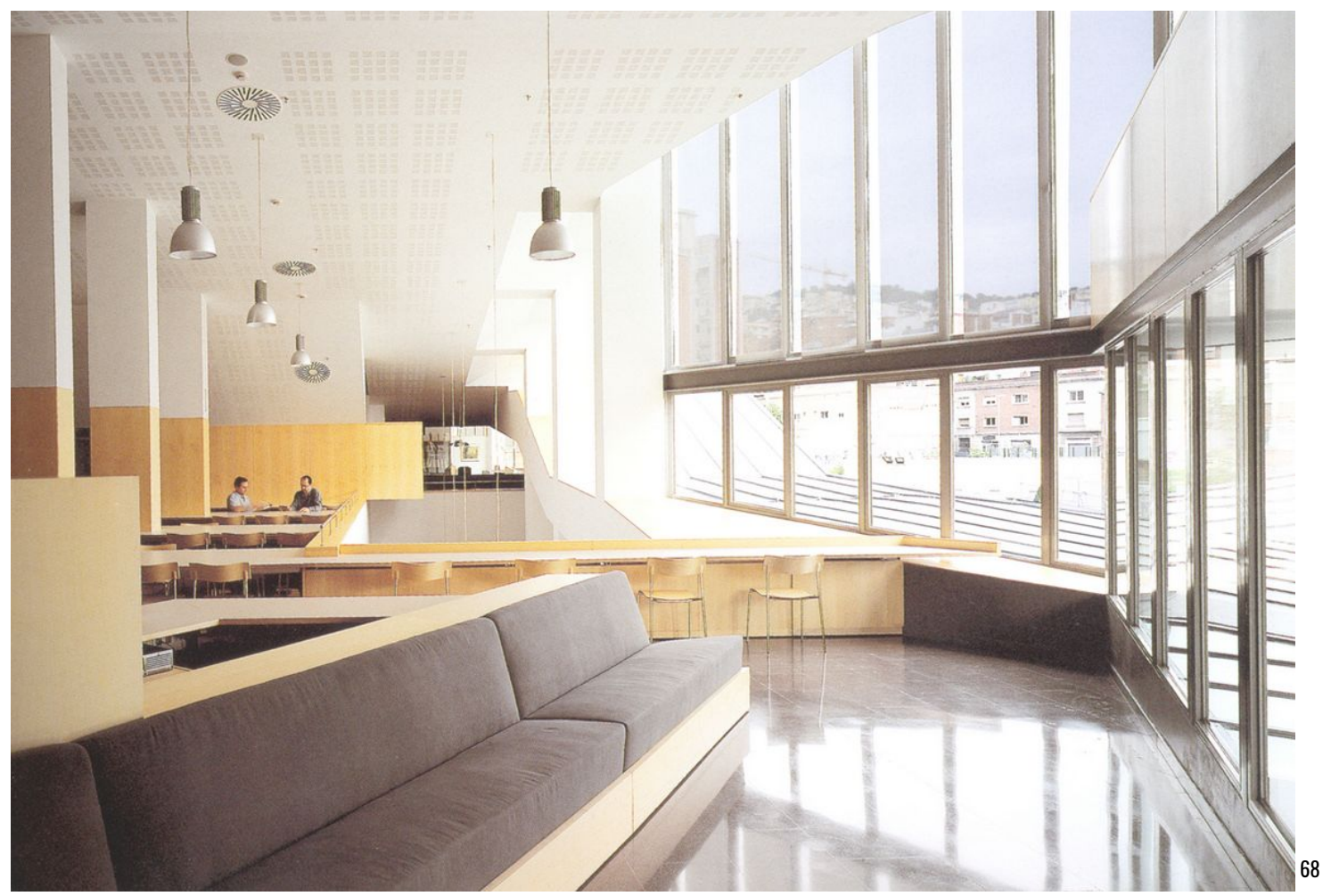

Fig. 2e

What happens when the book is no longer a spatial delineator? When the book, the bookcase, and the corridors between become less prioritized in the manipulation of the spatial order and semblance of library space? In the examples presented there is a perspective of the recent interpretations of public as a type of physical influence and context as a socio-spatial structure to generate a public library's image. Yet what is possible to see in the three cases, is the distribution of program that centers on the aspects of socialization and the potential intimization of space. In all these cases, including the recent renovations within the 1927 plan of the Parkway Central Library, the book and the bookcase do not disappear. Their language of demarcation and their nature of object massing remain present and perhaps are even emphasized as they serve a type of soft-boundary between spaces. In the North Beach Branch Library, it is not the singular book that defines space but rather the accumulation and integration within an interior

${ }^{68}$ Ibid. 
landscape. In essence, they become a new wall type that prioritizes "perforated" divisions through the movement and shifting of books while recalling itself as an accessible spatial field of knowledge. The transformation of "book" to the eventual production of library space provides a foundation on which the public, architects, and the various library stakeholders can contemplate the spatial construction vis-à-vis the book as a social and spatial delineator. As the three examples have revealed, there is evident desire to continue to formulate engagement with public as part of the increasing resignification of library as community. In this situation, the public library appears to dissolve its former identity as institutional object of the urban landscape into a continuation landscape of the public-context interface. 


\section{Bibliography}

Archdaily, 2014. North Beach Branch Library, Exterior.

https://www.archdaily.com/580711/north-beach-branch-library-lms-architects

Ibid.

Ibid.

Ibid.

Benjamin, Walter. "Paris: capital of the nineteenth century." Perspecta (1969): 165-172.

"Benjamin Franklin's Junto Club and Lending Library of Philadelphia" National Humanities Center Resource Toolbox. http://nationalhumanitiescenter.org/pds/becomingamer/ideas/text4/juntolibrary.pdf. The Junto Club was an organized weekly group promoted by Benjamin Franklin to discuss the "improvement of citizens...and [form] better acquaintance with the general sentiments of the inhabitants"

Bolton, Charles Knowles. American Library History. No. 1. American library association publishing board, 1911.

Book of Hours, Use of Sarum ("Anne Boleyn"s Book of Hours"),BL, Kings MS 9 : c 1500; Book of Hours, Use of Sarum,imperfect,BL.

Book of Hours, Book of Hours, Use of Rome ('The Dunois Hours'),BL.

Buschman, John, "Wayne A. Wiegand, Part of Our Lives: A People's History of the American Public Library," The Library Quarterly 86, no. 4 (October 2016): 476-478: https://doi.org/10.1086/688022

Bourkie, Andrew F. G., Alain Boureau, Marie-Elisabeth Ducreux, Christian Jouhaud, Paul Saenger, Catherine Velay-Vallantin, and Lydia G. Cochrane. The Culture of Print: Power and the Uses of Print in Early Modern Europe. Edited by Chartier Roger. Princeton University Press, 1989. http://www.jstor.org/stable/i.ctt7zvws2.

Carlos Cachon Grafico, 2014. Biblioteca Jaume Fuster [.] Barcelona. http://carloscachongrafico.blogspot.com/2011/11/biblioteca-jaume-fuster-barcelona.html

Chappell, Warren, and Robert Bringhurst. A Short History of the Printed Word. Hartley \& Marks Publishers, 1999.

Cinel, Dino. From Italy to San Francisco: The Immigrant Experience. Stanford University Press, 1982.

Contreni, John. "The Carolingian Renaissance: Education and Literary Culture.” Chapter. In The New Cambridge Medieval History, edited by Rosamond McKitterick, 2:709-57. The New Cambridge Medieval

“Digital Collections: About the Library-History," Free Library of Philadelphia, https://libwww.freelibrary.org/digital/feature/75th/history

Duffy, Eamon. Marking the Hours: English People and Their Prayers 1240-1570. Yale University Press, 2006 
Elliott, Joseph. ELEVATION OF MAIN ENTRANCE, SOUTH FRONT - Free Library of Philadelphia, Central Library, 1901 Vine Street, Philadelphia, Philadelphia County, PA. Photograph. From Library of Congress Prints and Photographs Division, Historic American Buildings Survey.

http://www.loc.gov/pictures/item/pa4067.photos.573839p/

Esmiol,A, "Populous District Enjoys Prosperity," San Francisco Call (San Francisco, CA), Jan. 22, 1910.

Elliott, Joseph. NORTH REAR ELEVATION - Free Library of Philadelphia, Central Library, 1901 Vine Street, Philadelphia, Philadelphia County, PA. Photograph. From Library of Congress Prints and Photographs Division, Historic American Buildings Survey. http://www.loc.gov/pictures/item/pa4067.photos.573835p/

Free Library of Philadelphia. "Parkway Central Booklet." https://drive.google.com/file/d/0By18SiaBMoq3a2N0d0Y1Uk5zSzQ/view

Ground floor plan, steel-frame version of the Central Library of the Free Library of Philadelphia, 1922. Floor Plans. Free Library of Philadelphia: Philadelphia, PA. https://libwww.freelibrary.org/digital/item/2772.

Harris, Michael H. 1975. The Role of the Public Library in American Life : A Speculative Essay. Occasional Papers University of Illinois, Graduate School of Library Science, No. 117. Champaign: University of Illinois, Graduate School of Library Science

Ibid.

Ibid.

Ibid

Huguet Gil,Meritxell, “ PLAZA LESSEPS: De Els Josepets a la Jaume Fuster, evolución de una plaza, y de la concepción de espacio urbano (Lesseps Plaza: From Josepets to Jaume Fuster, Evolution of a Plaza and its Conception)," Master and Theory in Practice of Architecture Projects, Politechnic University of Catalonia. 2010

"Illuminated Manuscripts Glossaries-Girdle book," British Library, http://www.bl.uk/catalogues/illuminatedmanuscripts/glossg.asp

Kalliroe, Linardou, "Illuminated Byzantine Psalters", The British Library: Greek Manuscripts. https://www.bl.uk/greek-manuscripts/articles/illuminated-byzantine-psalters\#

Ibid.

Ibid.

Lefebvre, Henri, and Donald Nicholson-Smith. The production of space. Vol. 142. Blackwell: Oxford, 1991: 69-70

Ibid.

Ibid.

Ibid.

Ibid. 
Mack, Peter. "Rhetoric, Ethics and Reading in the Renaissance." Renaissance Studies 19, no. 1 (2005): 1-21. http://www.jstor.org/stable/24416880.

Marek Jarosz Photo, 2014. Jaume Fuster Library, Barcelona,. http://marekjarosz.allyou.net/8572817/jaume-fuster-library

Ibid.

Periodical Room, now Philbrick Popular Library of the Free Library of Philadelphia. Photographic Prints. https://libwww.freelibrary.org/digital/item/655

Reinburg, Virginia. French Books of Hours: Making an Archive of Prayer, c. 1400-1600. Cambridge University Press, 2012.

Ticknor Bros Inc. Bird's-eye view from City Hall, showing Benjamin Franklin Parkway, Philadelphia, Pa.. Postcard. From Boston Public Library Tichnor Brothers collection. https://commons.wikimedia.org/wiki/File:Bird\%27s-eye view from City Hall, showing Benjamin Fra nklin Parkway, Philadelphia, $\mathrm{Pa}$ (69401).jpg

Ticknor Bros Inc. BFree library and municipal court, 20th Street and Benjamin Franklin Parkway, Philadelphia, Pa... Postcard. From Boston Public Library Tichnor Brothers collection.

https://commons.wikimedia.org/wiki/File:Free_library_and_municipal_court,_20th_Street_and_Benjami n_Franklin_Parkway,_Philadelphia,_Pa_(69399).jpg

https://commons.wikimedia.org/wiki/File:Bird\%27s-eye_view_from_City_Hall,_showing_Benjamin_Fra nklin_Parkway,_Philadelphia,_Pa_(69401).jpg

Naudé, Gabriel, Victoria Richmond, John Cotton Dana, and Ruth Shepard Granniss. News from France, Or, A Description of the Library of Cardinal Mazarin Preceded by the Surrender of the Library (now Newly Translated): Two Tracts Written by Gabriel Naudé. AC McClurg, 1907.

Saenger, Paul. Space Between Words: The Origins of Silent Reading. Stanford University Press, 1997.

Stein, Wendy A. “The Book of Hours: A Medieval Bestseller.” In Heilbrunn Timeline of Art History. New York: The Metropolitan Museum of Art, 2000-. http://www.metmuseum.org/toah/hd/hour/hd_hour.htm (June 2017)

"The Promise of the Vatican Library," University of Nortre Dame and Vatican Library. https://vaticanlibrary.nd.edu/assets/197970/vatican library conference program.pdf

Gray, Hanna H. "Renaissance Humanism: The Pursuit of Eloquence." Journal of the History of Ideas 24, no. 4 (1963): 497-514. doi:10.2307/2707980.

“The Shape of Paper,'Institut d'Histoire du Livre (Institute of the History of Books). http://ihl.enssib.fr/paper-and-watermarks-as-bibliographical-evidence/the-shape-of-paper

Kaufman, Paul. "The Community Library: A Chapter in English Social History." Transactions of the American 
Philosophical Society 57, no. 7 (1967): 1-67. doi:10.2307/1006043.

Osarte, Xavier. “Bliblioteca Jaume Fuster (Jaume Fuster Library) : Josep Llinas.” Quaderns d'arquitectura $i$ Urbanisme, 2005; No. 248, p. 46-63.

Peterson, Jon A. "The city beautiful movement: Forgotten origins and lost meanings." Journal of Urban History 2 , no. 4 (1976): 415-434.

San Francisco Recreation and Park. "Joe DiMaggio Playground Improvement Project”. SFRecPark. http://sfrecpark.org/project/joe-dimaggio-playground/

Serchs i Serra, Jordi. "Guia de l'Arxiu Municipal del Districte de Gràcia," Ajuntament de Barcelona Arxiu Municipal de Barcelona (1997): 5-7.

Spur Project Review. North Beach Branch Library and Joe DiMaggio Playground.” Spur. https://www.spur.org/sites/default/files/events pdfs/04.06.11\%20The $\% 20 \mathrm{New} \% 20$ North $\% 20 \mathrm{Beach} \%$ 20Library\%20-\%20Marsha\%20Maytum.pdf

Step 1-11.Photographic Prints. Free Library of Philadelphia: Philadelphia, PA. https://libwww.freelibrary.org/digital/item/51. (accessed Mar 24, 2018)

Transverse section. Elevations. Free Library of Philadelphia: Philadelphia, PA. https://libwww.freelibrary.org/digital/item/711. Pepper Hall highlighted in red (leftmost), this section exIhbits the changes in scale from the two floors high space of Pepper Hall, to the compressed scale entrance, and the spatial extension of the grand staircase.

Walsby, Malcolm, and Graeme Kemp, eds. The book triumphant: print in transition in the sixteenth and seventeenth centuries. Vol. 9. Brill, 2011.

WHYY. "New edition of Philbrick Hall lends more space to Free Library” https://whyy.org/articles/29pclibrary/

Williams, Richard. "Architecture and Visual Culture." Exploring Visual Culture: Definitions, Concepts, Contexts (2005): 102-116.

Williams, Robert V. "The Public Library as the Dependent Variable: Historically Oriented Theories and Hypotheses of Public Library Development." The Journal of Library History (1974-1987) 16, no. 2 (1981): 329-41. http://www.jstor.org/stable/25541199.

Ibid.

Ibid.

Ibid.

Ibid

"Blog: The Carnegie Libraries of the Free Library: Past, Present, and Future," Free Library of Philadelphia, https://libwww.freelibrary.org/blog/post/2271 